Historic, Archive Document

Do not assume content reflects current scientific knowledge, policies, or practices. 

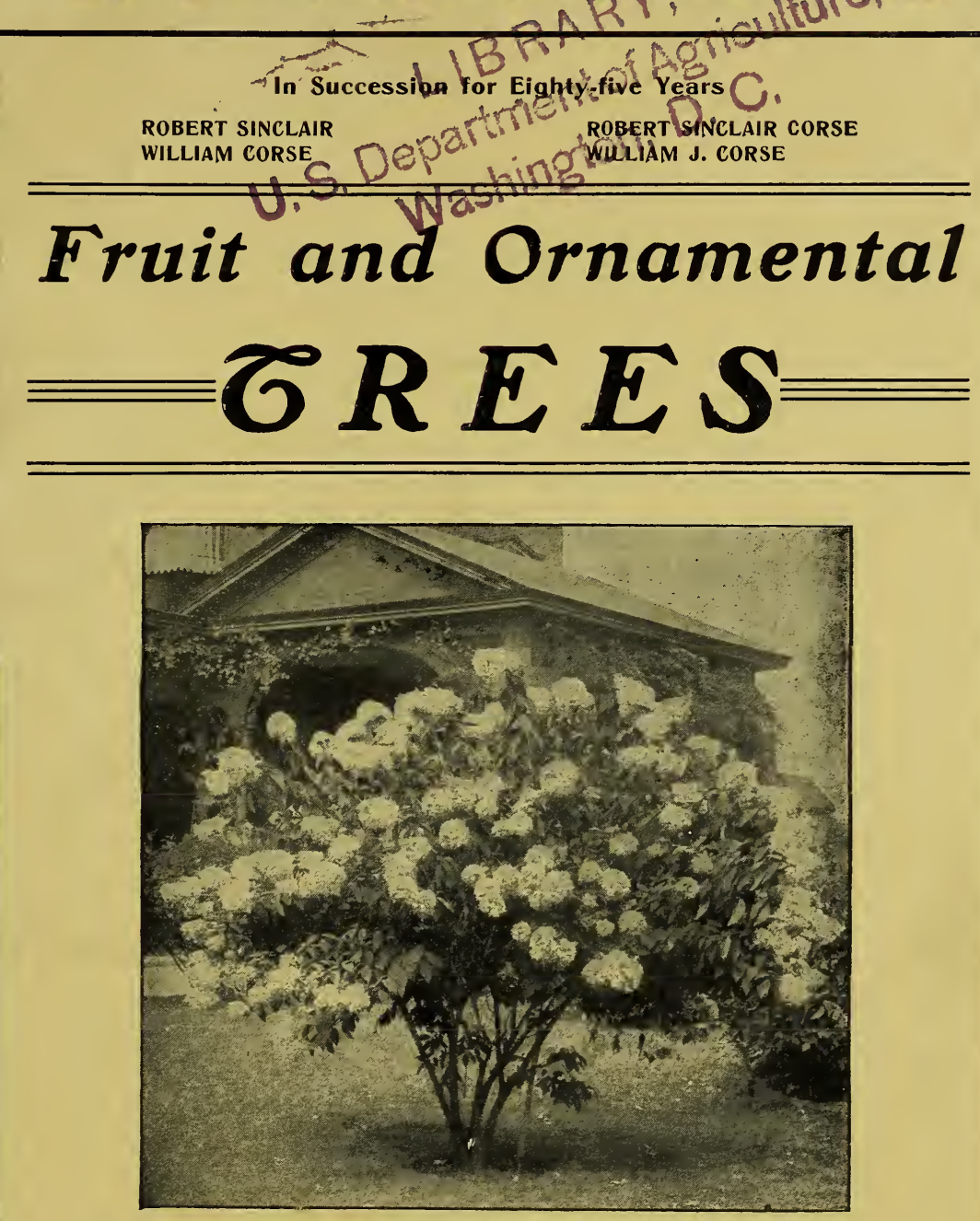

HYDRANGEA

\section{Sinclair Nurseries} WM. J. CORSE, Proprietor

\section{BALTIMOR-E, MARYLAND}

My Nurseries are situated on Southern Avenue, midway between Gardenville on Belair Avenue, and Lauraville on Harford Avenue.

Electric Cars to the Nurseries on either road. BOTH PHONES 


\section{CUBANOLA - The Best Insecticide and Bug-Killer.}

Having tried everything in this line, I find this is the best of all. Not poison, simply suffocates the insect as soon as inhaled; is not dangerous to use on vegetables, even if eaten immediately after applying it. This is especially good to use on the roots of trees when planting them, to destroy insects, and to wash the body of trees, to kill the insects and keep the bark healthy. For sale in any quantity.

1 lb., 15c. ; 10 lbs., $\$ 1.00 ; 100$ lbs., $\$ 5.00$.

\section{SPECIAL MIXTURE}

Fertilizer and insecticide combined. Unequalled for a lawn dressing. Will kill all insects and bugs, and drive away moles. It is the best thing for mixing with soil for potting plants and in frames, greenhouses, etc. 1 lb., 15 c.; 5 lbs., 50 c.; 10 lbs., $\$ 1.00$.

\section{SULPHO-TOBACCO SOAP}

The very best insecticide for greenhouses and conservatories. Dissolve about two ounces of the soap to a gallon of warm water. Apply when cold with atomizer, sprinkler, or sponge. For animals make a lather and apply with hand or sponge. Price, 20c.; by mail, 28c.

Spray Pumps and Atomizers, the very best make. Death to Lice, an insect powder for poultry houses; the best thing that can be used. Dust Sprayers, for applying insect powder. Scale Killers, best kinds. Bordeaux Mixture, in powder. Bordeaux Mixture, in liquid. Flower of Sulphur, Bluestone and Fungicides of best kinds. Lawn Grass Seed, of the very best mixtures.

\section{TESTIMONIALS}

Mr. Wm. J. Corse, Baltimore, Md.

Rossville, Baltimore County, Md., May 16, 1905.

Dear Sir-I write this to express my appreciation of your Insecticide and Bug-Killer, which I have used with highly gratifying results on small fruits, plants, roses, etc., and have found it most satisfactory in destroying lice, worms, slugs, and the various insects which attack young vegetables. It was of great use to us on cabbage, vines, asparagus, and in fact, as an insect destroyer, I believe this preparation has never been excelled, and seldom equalled.

Very truly yours,

E. G. TAYLOR.

Mr. Wm. J. Corse, Baltimore, Md. $\quad 1331$ Chestnut Hill Ave., Baltimore, Md., May 19, 1905.

Dear Sir-After having tried your Insecticide and Bug-Killer on roses, plants and vegetables, and specially as a remedy for lice in the poultry-house, where I had no end of trouble, I felt like writing you a word as to the excellent results I had in using it. It is certainly one of the best, if not the best, thing in that line I have ever used, and you can refer to me at any time as to its good qualities as an insect destroyer.

MRS. ADOLPH KUHEN.

Wm. J. Corse, Baltimore, Md.: $\quad$ Fullerton, Baltimore County, June 1st, 1905.

Dear Sir-The Insecticide and Bug-Killer I got from you is the finest thing I ever used. It drove all the mice out of my frames, and killed all the insects on my vegetables.

\section{DISTANCE TO SET STOCK}

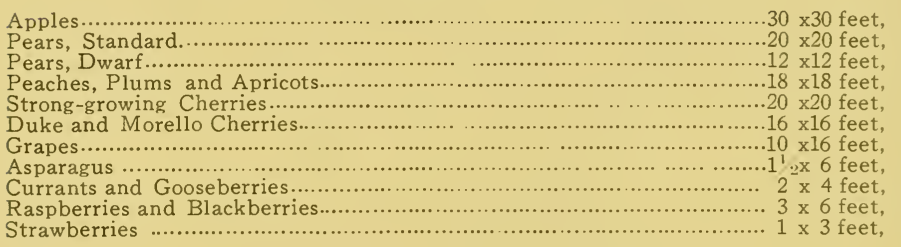

48 trees per acre 110 trees per acre 200 trees per acre 135 trees per acre 110 trees per acre 170 trees per acre 275 vines per acre 4,840 plants per acre 5,450 bushes per acre 2,420 plants per acre 14,500 plants per acre

\section{PLANTING}

1st. Dig holes in the first place large enough to admit the roots of the tree to spread out in their natural position; then, having the tree pruned, let one person hold it in an upright position, and the other shovel in the earth, carefully putting the finest and the best from the surface in among the roots, filling every interstice, and bringing every root in contact with the soil. When the earth is nearly filled in, a pail of water may be thrown on to settle and wash in the earth around the roots; then fill in the remainder and tread gently with the foot. The use of water is seldom necessary, except in dry weather early in fall or late in spring. Guard against planting too deep; the trees, after the ground settles, should stand in this respect as they did in the nursery. Trees on dwarf stock should stand so that all the stock be under the ground, and no more. In very dry, gravelly ground the holes should be dug twice the usual size and depth, and filled in with good loamy soil.

\section{STAKING}

2d. If trees are tall and much exposed to winds, a stake should be planted with the tree, to which it should be tied in snch a manner as to avoid chafing. A piece of matting or cloth may be put between the tree and the stake.

\section{MULCHING.}

3d. When the tree is planted throw around it as far as the roots extend, and a foot beyond, five or six inches deep of rough manure or litter. This is particularly necessary in dry ground, and is highly advantageous everywhere, both in spring and fall planting. It prevents the ground from baking or cracking, and maintains an equal temperature about the roots.

\section{AFTER-CULTURE}

4th. The grass should not be allowed to grow around young trees after being planted, as it stunts their growth. The ground should be kept clean and loose around them until at least they are of bearing size. 


\section{Apples}

\section{SUMMER}

Astrachan Red. Large, roundish, nearly covered with deep crimson, overspread with a thick bloom; juicy, rich, acid; beautiful. The tree is a vigorous grower, with large foliage, and a good bearer. August.

Early Harvest (Yellow Harvest). Medium to large; pale yellow; fine flavor. Tree a moderate, erect grower and a good bearer. June and July.

Early Strawberry. Medium size, roundish, sometimes conical; very handsomely striped with red; excellent subacid; good grower and productive. August.

Early Ripe. This fine Apple, coming in as it does immediately after the Early Harvest, fills a want long felt by the orchardist. Its large size, handsome appearance and good bearing qualities combine to make it the most profitable market variety of its season. The tree is hardy and of vigorous growth; fruit large, yellowish white; flesh white, juicy, subacid; fine for the table or for cooking. July 1.

Yellow Transparent. Earliest ripening Apple known. Of Russian origin; medium size; light, transparent, lemonyellow; flesh juicy, pleasant subacid; very early.

\section{AUTUMN}

Duchess of Oldenburg. Large size, roundish; streaked with red and yellow; flesh whitish, juicy and sprightly subacid; ripens early in the fall. Tree a vigorous grower and quick bearer. It is of Russian origin. September.

Fall Pippin. Very large, roundish; yellow, with scattered dots; mellow and rich. Vigorous and fine bearer. October to December.

Gravenstein. Large; bright yellow, penciled and marbled with red and orange; crisp, juicy, high flavorer. Vigorous and productive. Sept. and Oct.

Maiden's Blush. A very beautiful Apple of good quality; medium size; pale yellow, with a red cheek. Sept. and Oet.

Red Bietigheimer. A new and very valuable German variety. Very large; light yellow, nearly covered with red; purplish crimson when exposed to the sun; flesh subacid and pleasant. Tree a magnificent spreading grower, bearing immense crops. September.
Summer Rambo of Pennsylvania. Very large; yellow ground, striped with red; flesh mild subacid, with an agreeable flavor. September.

Smokehouse. Fruit large, oblate; yellow ground, striped with red; flesh yellowish white, firm, juicy, crisp and rich, with a fine aromatic subacid flavor. Productive; should have a place in every orchard. September to December.

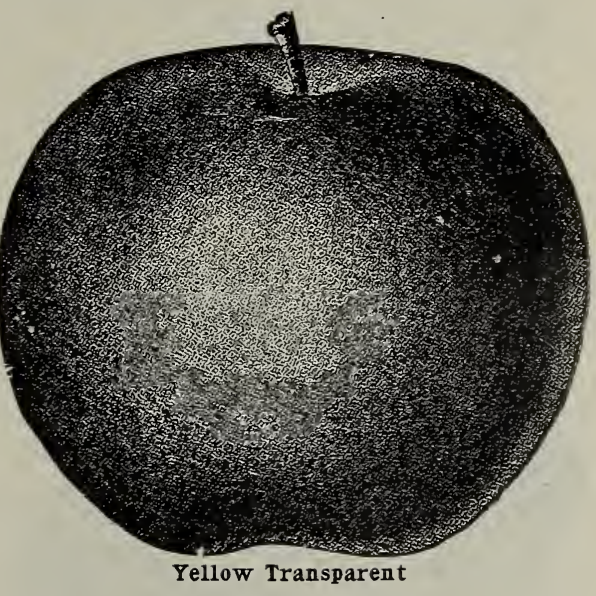

\section{WINTER APPLES}

Arkansas Black. Tree a beautiful, upright grower, with very dark young wood; an abundant bearer. There is scarcely an Apple that is more brilliant. ly colored. Large, round or slightly conical, regular, smooth, glossy; yellow, where not covered with deep crimson almost black; flesh very yellow, firm, fine, juicy; flavor subacid, pleasant, rick and excellent. A long keeper. One of the most profitable and attractive Apples.

Bismarck. A German Apple of recent introduction, remarkable for very early bearing. Fruit is large, of brilliant color and very handsome.

Baldwin. Rather large, nearly round, narrowing a little to the eye; deep, dull red; juicy, rich and fine flavored. One of the best where the soil suits it. December to March.

Ben Davis. Large, conical; yellowish, overspread and striped with red; flesh white, juicy, subacid. A hardy, erect grower and early, abundant bearer. One of the best western Apples. December to March. 
Dominie. A large, flattened, greenish yellow Apple with red stripes; flesh white, tender, juicy. Good grower; productive. J'inest in the west. November to April.

Delaware Winter. Remarkable for its long-kecping qualities, having been kept in goor coudition until August with only ordinary care. Fruit medium to large, round; bright red, highly eolored; flesh fine-grained, crisp, juicy, excellent, subacid. Tree a vigorous grower and an abundant and early bearer. Very valuable in middle states. Those who try this variety will not regret it.

Fallawater. Very large, globular; yellowish green, with dull red cheek, and large gray dots; flesh greenish white, juicy, erisp, subacid. Strong grower and productive. November to Mareh.

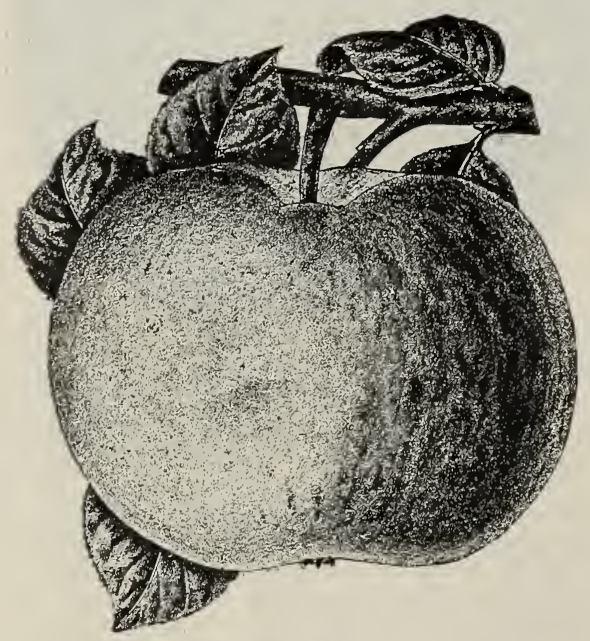

Rome Beauty

Grimes' Golden. Medium, roundish oblate; yellow, with red in the sun; flesh yellow, crisp, juicy, spicy, subacid. Hardy, upright grower and very productive. December to Mareh.

Hubbardston Nonsuch. Large, roundish, oblong; yellow, striped and splashed with bright red; flesh yellow, juicy, sweet, vinous. November to Jannary.

Johnson's Fine Winter, or York Imperial. Medium size, truncated oval, angular; skin greenish yellow, nearly eovered with bright red; flesh tender, erisp, juicy, aromatic; an enormous bearer, and hangs well on the tree. It is also a good keeper, retaining its flavor to the last. All things consider- ed, it is scarcely second to any in the catalogue as a profitable orchard variety. February to April.

Long Island Russet, or Golden Russet of Massachusetts. Medium size, golden russet, with a dull red cheek; tender, rich, with a mild, subacid flavor. December to March.

Langford's Seedling. A seedling of great promise, from Langford Bay, Kent county, Md. Large size, red striped, good quality; especially valuable for southern culture. Keeps until May and June with ordinary care. Tree hardy and a good grower; bears annual erops. No farmer or fruit-grower should be without this Apple.

Mammoth Black Twig (Paragon and Arkansas). Resembles the Winesap in every way, except that the tree is a much more vigorous grower, more hardy, and the fruit is much larger, many specimens being 12 inches in eircumference. Color even a darker red, flesh firmer, and, most important of all, a better keeper. Flavor milder, more of a pleasant subacid. January to May.

Paradise Winter Sweet. Large, regularly formed, roundish; skin fair and smooth, dull green when picked, with a brownish blush; flesh white, finegrained, juicy, sweet; productive. Nov. to February.

Rome Beauty. Of moderate growth and a late bloomer. Fruit large; yellow, shaded and striped with bright red; flesh yellowish, tender, juicy, good. November to January.

Seek-no-Further (Westfield). Above medium; dull red, dotted with russet; flesh white, fine-grained, with a rich flavor; excellent. December.

Smith's Cider. A handsome fruit, large, oblong, somewhat flattened; skin yellow, changing to red; flesh tender, juicy, crisp, with pleasant, subacid flavor. December.

Wagener. Medium, dark red; flesh mild, tender and subacid; an excellent variety. Abundant bearer and goorl grower. December to March.

Winesap. Medium roundish; deep red; good quality; keeps well. Tree a fair grower and good bearer; very popular. December to May.

\section{APPLES-CRAB}

Hyslop. Large, deep erimson; one of the most beautiful Crabs; very popular. Oct. to Jan.

Transcendent. Immensely productive, bright red, one of the most popular. Sept. to Oct. 


\section{Standard Pears.}

\section{FIRST CLASS-SUMMER}

Bartlett. Large size, with often a beautiful blush next the sun; buttery, very juicy and high-flavored. Tree a strong grower and bears early and abundantly. Last of August and first of September.

Clapp's Favorite. Very large; yellowish green to full yellow when ripe, marbled with dull red in the sun, and covered with small russety specks; vinous, melting and rich. Last of $\mathrm{Au}$ gust. Ripens best when gathered very early.

Clairmont. An early variety, rich, juicy and aromatic. A beautiful table pear. Very prolific and comes into fruiting very early.

Doyenne d'Ete. Small, melting, sweet; yellowish. Tree vigorous and productive. August.

Madeleine. Medium size; yellowish green; melting, sweet and delicate; fair grower, early bearer. First of August.

Manning's Elizabeth. Below medium size; clear yellow, with a lively red cheek, dotted with brown and red dots; flesh juicy and melting. A beautiful dessert fruit. Desirable for amateur growers.

Tyson. Medium size; yellow, with a red cheek; buttery, melting and fine; excellent. September.

\section{SECOND CLASS-AUTUMN}

Belle Lucrative (Fondante d'Automne). Large; melting and delicious. A fair, upright grower; bears early and abundantly. First quality. Sèpt. and Oct.

Beurre d'Anjou. Large size, pyriform; light green, with russet and red cheek; rich, melting, and of excellent flavor. Tree a fine grower, very healthy and productive. It bears transportation well and is an excellent market'sort. In season during late fall and early winter.

Doyenne Boussock. Large; rough, yellow; buttery, sweet. Vigorous. September and October.

Duchesse d'Angouleme. Very large; flesh greenish yellow, spotted with russet; buttery, very juicy and rich. Does best on quince; excellent. Oct to Dec.
Howell. A fine, large, very handsome Pear; a good grower, and does well on quince; very good. Sept and Oct.

Louise Bonne de Jersey. A large, beautiful Pear. Yellow, with a dark red cheek; melting, buttery and rich. Tree a rapid, erect grower and most abundant bearer; best on the quince. Should be in all collections. September and October.

Seckel. Small; rich yellowish brown; one of the best and highest-flavored Pears known; productive. Sept. and Oct.

Sheldon. Medium to large; yellow and somewhat russety; an excellent variety; one of the best. Tree a fine grower; productive. October.

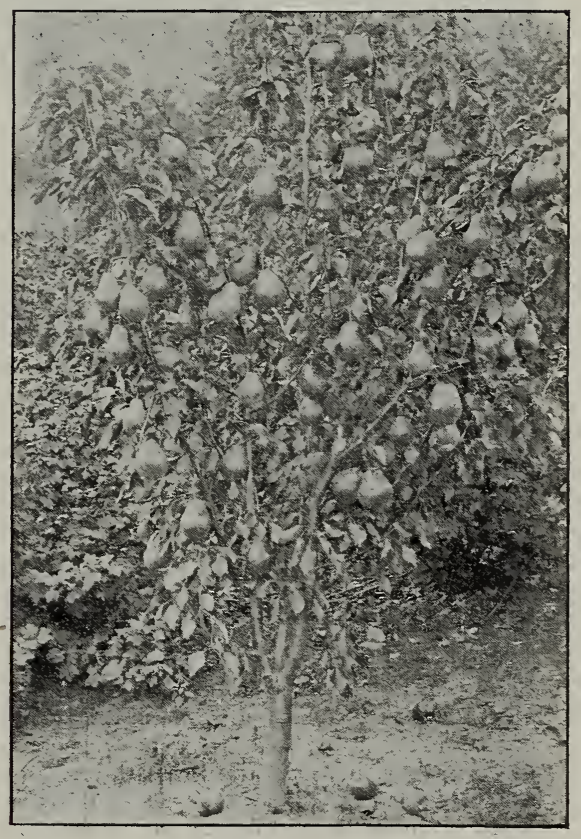

Dwarf Pear Tree

\section{THIRD CLASS-WINTER}

Beurre Clairgeau. Very large, pyriform; yellow and red; texture of Beurre Bosc; flesh yellowish, nearly melting. Tree a fine grower and an early, abundant bearer; a magnificent market fruit. November to January.

Kieffer. Appears to be growing in favor as a late Pear. It is certainly a beautiful grower and healthy; while 
its flavor is not of the best, it is of a fine size, cans as weil as any other variety, and is appreciated on account of its late ripening. November.

Lawrence. Above medium size, yellow, thickly dotted; has a very fine rich flavor; one of the best. Tree a moderate grower and productive. Dec. and Jan.

\section{UWARF PEARS}

Special list of varieties of Pears suitable for growing as dwarfs on the Angers quince stock:

$\begin{array}{ll}\text { Beurre d'Anjou, } & \text { Howell, } \\ \text { Clapp's Favorite, } & \text { Lawrence, } \\ \text { Duchesse d'Angouleme, } & \text { Seckel, } \\ \text { Manning's Elizabeth, } & \text { Tyson. }\end{array}$

\section{Cherries}

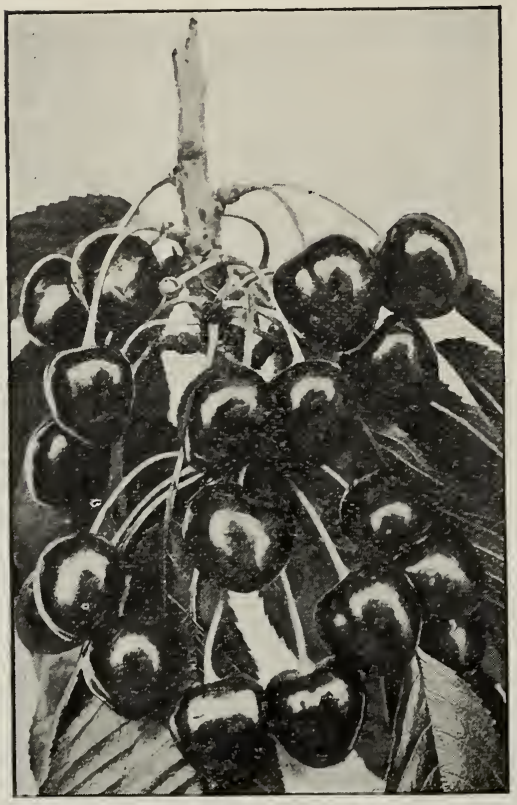

Black Tartarian

\section{FIRST CLASS-HEART}

Black Tartarian. Very large; purplish black; half tender; flavor mild and pleasant. Tree a remarkably vigorous, erect and beautiful grower, and an immense bearer. Ripe last of June and beginning of July. One of the most popular varieties in all parts of the country.

Governor Wood. The finest of Dr. Kirtland's seedlings. Fruit large, roundish, heart-shaped; skin light yellow, shaded and marbled with bright red; juicy, sweet and rich. Middle to end of June.

Knight's Early Black. Large; black; tender, juicy, rich and excellent. Tree vigorous and very productive; branches spreading. Ripe a few days before the Black Tartarian.
Ohio Beauty. Large; light yellow and red; firm, juicy, sweet and good. Tree spreading, vigorous and productive. Middle to end of June.

\section{SECOND CLASS-BIGARREAU}

This is chiefly distinguished from the preceding class by their firmer flesh. Tree vigorous, branches spreading, and foliage luxuriant, soft and drooping.

Bigarreau, or Yellow Spanish. Large; pale yellow, with a bright red cheek in the sun; flesh firm, juicy and delicious. One of the best, most beautiful and popular of all light-colored Cherries. Tree vigorous and productive. End of June.

Florence. A most excellent Cherry, and has the additional good quality of hanging a long time on the tree; color red; flesh firm, rich, sweet, fine flavor. Hardy and a good bearer. Ripens middle of July.

Napoleon Bigarreau. Very large; pale yellow or red; very firm, juicy and sweet. Vigorous grower and very productive. One of the best. July 1 .

Windsor. Very large, red, juicy and sweet; a very valuable late variety for market or family use.

\section{THIRD CLASS-DUKE AND MO- RELLO}

English Morello. Medium to large; blackish red; rich, acid, juicy and good. Very hardy and productive. August.

Early Richmond (Kentish). Medium size; dark red; melting, juicy, sprightly, rich acid flavor. This is one of the most valuable and popular of the acid Cherries, and is unsurpassed for cooking purposes. Tree a slender grower, with a roundish spreading head, and is exceedingly productive. The most hardy of all varieties; uninjured by the coldest winters. Ripens through June.

Montmorency Ordinaire. A beautiful, large red, acid Cherry. Larger than Early Richmond, and fully ten lays later. Very prolific and hardy. A variety of great value. Tree a free grower. 


\section{Peaches}

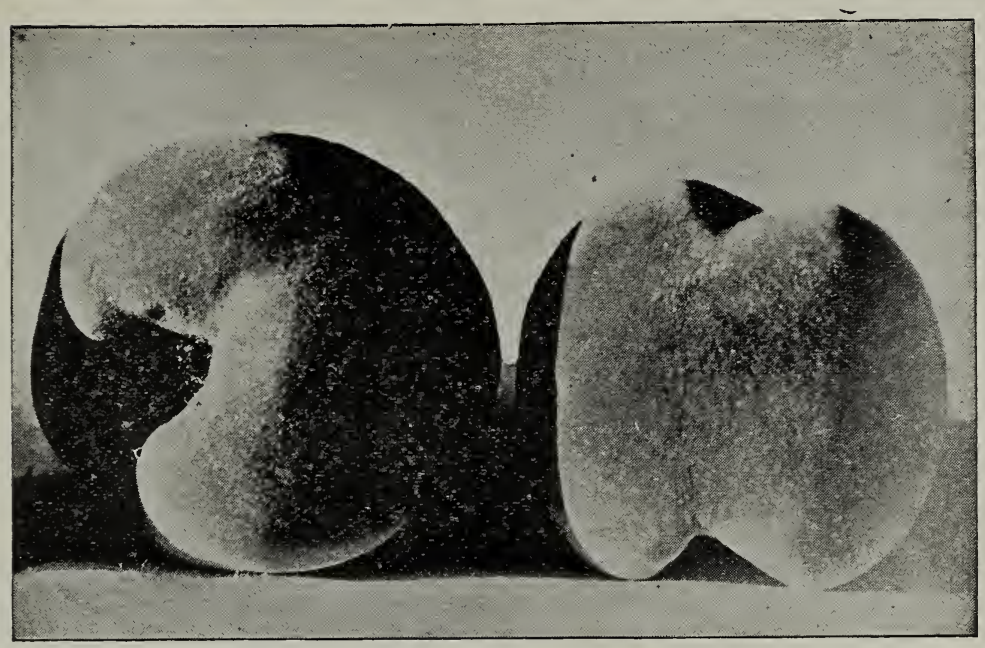

Chair's Choice

Chair's Choice. A new and valuable variety, which originated near Hawkins' Point, Anne Arundel county, Md. Fruit very large; yellow, deep flesh, vinous, of superior flavor; open, small srune; skin nearly covered with velvety red. Very profitable, and is steadily growing in favor; hardy and productive. Ripens between Crawford Late and Smock. One of the best. We have had much experience with this variety, and were the first to bud it with buds from the original tree. Many of our patrons have sent forth to us praise for its excellent qualities.

Cling Orange. A variety originating near Battle Creek, Mich., and much valued in that state. It is a very vigorous grower and a productive bearer of large orange-colored fruit of excellent quality; dark blush. September 20 .

Crawford's Early Melocoton (Early Crawford). This very beautiful yellow Peach is bighly esteemed for market purposes. Fruit very large, oblong; skin yellow, with a fine red cheek; flesh yellow, juicy, sweet and excellent. Tree vigorous, productive and hardy. August 15.

Crawford Late. Almost universally cultivated as the best of its season, and as a yellow-fleshed Peach is certainly unsurpassed in quality, and holds the first rank as a profitable market fruit. In some localities it appears not to bear so heavily as in others, but taken generally it is quite a favorite, and those who have not planted it should not fail to do so. It pays many handsomely. Ripens before Smock, about 1st to 5th of September.

Elberta. An exceedingly large, highcolored yellow Peach-a cross between Crawford's and Chinese Cling; juicy, high-flavored; probably the finest yellow freestone in existence, and a superb market sort. Ripens early in August.

Foster. A new very large Peach, resembling Crawford Early in appearance, but is larger and somewhat earlier; tree hardy and productive. August 15.

Fox's Seedling. Large; skin white, with red cheek; flesh melting, sweet and good; a desirable sort for canning or marketing, because it is late ripening. It appears to be a very good bearer and thrifty grower, and we think it will become very popular and much sought for. Ripens about September 8 , although its ripening varies according to locality.

Health Cling. Very large; creamwhite. An excellent late variety. Popular in the South, where it succeeds well.

Large Early York. A large and beautiful variety; white, with red cheek; flesh juicy and delicious. Tree vigorous and productive; one of the very best. August 15. 
Magnum Bonum. A very large, yellow Peach, with a firm, red cheek; flesh yellow, juicy and melting, excellent flavor. Tree vigorous and productive, and generally known as a great market variety; freestone. We have customers in Anne Arundel county who sent us some fruit from trees bought of us and, without exception, it was as fine as any of the Melocoton family, of which it is a member; they bring top prices. Ripens about September 5 .

Mountain Rose. A variety of great value. Very profitable for market, and is steadily growing in favor. Fruit large, roundish; skin whitish, nearly covered with light and dark rich red; flesh white, slightly stained at stone, juicy and sweet; separates freely from the stone. Follows Troth's Early.

Oldmixon Cling. Large; pale yellow, with red cheek; juicy, rich, high flavored. One of the best clingstones. Sept. 5 .

Oldmixon Free. A fine, large, productive variety, succeeding well in all localities, and well deserving of the high favor in which it is held as an orchard variety. Skin yellowish white, with a deep red cheek; flesh white, but red at the stone, tender, rich; indispensable. August 15.

Reeves' Favorite. Large; skin yellow, with a fine red cheek; flesh yellow, red at stone, juicy, melting, with a good vinous flavor. September 1.

Smock Freestone. Fruit large; skin light orange-yellow, mottled with red; moderately juicy and rich. Very prolific and a sure bearer; is is very extensively planted and appears to do well on many varieties of soil. It should not be omitted in any orchard grown for canning purposes. Some growers have preference for it. Ripens about September 12 .

Stump the World. Very large, roundish; skin white, with a bright red cheek; flesh white, juicy and good. September 1.

Troth's Early. A very early and excellent Peach of medium size; whitish, with a fine red cheek; flesh juicy, sweet and very good. One of the most popular and profitable varieties for early marketing; we are cultivating it largely for that purpose. July 30.

\section{Plums}

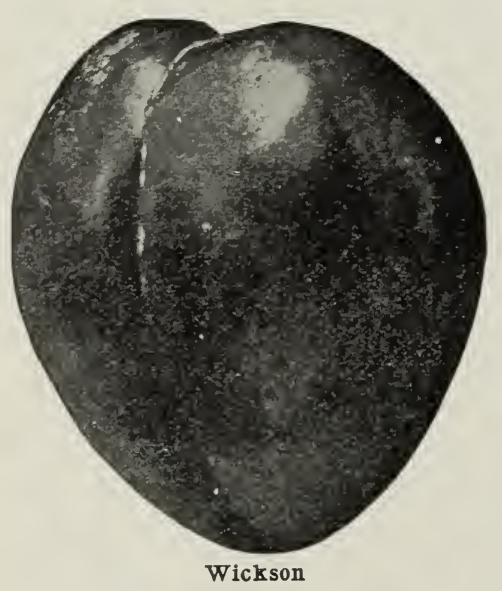

Abundance. This is a remarkable fruit indeed; both in tree and fruit it is unlike any other Plum. In growth it is so strong and handsome as to render it worthy of being planted as an ornamental tree, equaling in thrift and beauty the Kieffer pear, which it even excels in early and profuse bearing. Its propensity to early bearing is such that it loads in the nursery row, bending the limbs with weight of fruit until they sometimes break, and this is the case every year. The curculio has no effect upon it, the eggs failing to hatch and produce the destructive grub the same as with the Spaulding. The fruit is very large, showy and beautiful; amber, turning to a rich, bright, cherry color with a decided white bloom and highly perfumed. Season early-August. Stone small and parts readily from the flesh.

Admiral Togo. Of the number of Japan Plums which have appeared since the Abundance, Admiral Togo is the only one that is superior to it; it is large, of firm, dry flesh, rich in quality, and ripens about September 15th; of a golden yellow flesh; does not rot on the tree, goor keeper and is cureulio proof. Equals in size and beauty the California Plums, but far superior in quality.

Bradshaw. Fruit very large; dark violet-red; flesh yellowish green, juicy and pleasant. Tree very vigorous, ereet and productive. Middle of $\mathrm{Au}$ gust.

Burbank. Fruit large, nearly globular, clear cherry-red, with a thin lilac bloom; flesh a deep yellow, very sweet, with a peculiar and very agreeable flavor. Tree vigorous, beginning to bear at two years old. August. 
Damson, Shropshire. Originated in England. A Plum of fine quality; as free from the attacks of the curculio as the common Damson, and the same. color.

German Prune (Dominie Dull). Medium size, long, oval; juicy at first, but if allowed to hang on the tree becomes dry, rich ånd sweet; freestone. Tree very productive. September.

Hale. Large, golden-yellow, with red cheek; flesh yellow, very rich and juicy. Tree of tremendous vigor and luxuriance; ripens its fruit late; superb shipper.
Imperial Gage. Rathei large, oval; greenish; flesh juicy, rich and delicious; parts from the stone. One of the best growers; most productive and best of Plums. Middle of August.

Red June. Fruit medium to large: deep rermilion-red, with a handsome bloom, very showy; flesh light lemonvellow or whitish, firm and moderately juicy, of good, pleasant quality; cling to half eling; pit small. Tree vigorous and productive. One of the earliest.

Wickson. One of Burbank's introductions. Color deep red; flesh firm, dull yellow, with an aromatic flaror; an upright grower. One of the latest.

\section{Quinces}

Champion. Tree extremely hardy, of stout, rugged, upright growth, a profuse and regular bearer, and its early bearing is remarkable, commencing to produce fruit at three and four years old. Fruit large, ovate pyriform in shape, and of a lovely yellow color, rendering it very showy and handsome; flesh tender; in fine flavor and odor it is fully equal to the well-known Orange variety. Ripens very late and will keep until Christmas.

Meech's Prolific. This valuable new Quince has awakened great interest throughout the country, and promises to revolutionize Quince culture entirely. They are remarkable for their early and regular bearing, and for their wonderful productiveness, sometimes bearing when only two years old, and afterwards such abundant bearers that a vigorous thinning of the fruit is required to prevent injury from overbearing. It is shaped like a pear with a smooth, fine skin of bright orangeyellow, and very large, averaging, under good culture, 12 to 15 ounces each. Its cooking qualities are unsurpassed, being quite free from the hard lumps so objectionable in many other rarieties.

\section{Hardy Native Grapes}

\section{FIRST CLASS-BLACK}

Clinton. Bunches small and compact; good table Grape; keeps well, valuable for wine, a free grower, and profuse bearer; ripens early.

Concord. Bunches large; fruit juicy, sweet and good; vine very hardy and vigorous. No variety is more universally popular. Middle or last of September.

Worden. This excellent Grape has come to the front by merit alone. It is as hardy, healthy, vigorous and productive as the Concord, of which it is a seedling, but better in quality, sweeter, larger in bunch and berry and several days earlier. The worst that can be said of it is that it will crack under conditions that the Concord will. Very valuable for garden and vineyard.
Moore's Early. Raised by J. B. Moore, Concord, Mass. Bunch and berry as large as Wilder; black, with a blue bloom; quality better than Concord; ripens ten days before Hartford. It has received thirteen first premiums from the Massachusetts Horticultural Society, and in 1877 was awarded a special premium of sixty dollars. One of the best black Grapes.

\section{SECOND CLASS-RED}

Agawam. Tigorous and productive; bunches large and quite compact; berries large, dark red and juicy. Ripens about first of October.

Brighton. A cross between the Concord and Diana Hamburg. Resembles Catawba in color and in size. and form of bunch and berry. Flesh rich, sweet 
and of the best quality, equal if not superior to Delaware. Ripens early, with the Delaware, Eumelan and Hartford. Tine productive and vigorous.

Catawba. Large, red; very sweet; good flavor and old variety. Needs good, rich soil and good culture.

Woodruff Red. A new Grape of iron-clald hardiness. A rank grower and very healthy. The fruit is large in bunch and berry, attractive, shouldcred, sweet and of fair quality, but somewhat foxy. Desirable as a market varicty where many others fail. It ripens soon after Coucord.

\section{THIRD CLASS-WHITE}

Moore's Diamond. This fine new white Grape was raised by Dr. Jacob Moore (the originator of the famous Brighton) and is a hybrid between the Concord and Iona. The vine, a pure native, is very vigorous, with dark, healthy fo- liage, entirely free from mildew. Jt bas proved very hardy without protection, and is extremely prolific. Bunches large, compact, slightly shouldered; berry greenish white, tinged with yellow; about the size of Concord; skin smootli, free from spots or dots.

Niagara. Said to be a cross of Concord and Cassaday. Bunch medium to large, compact, occasionally shouldered; berry large, roundish, uniform; skin thin but tough, pale green at first, changing to pale yellow when fully ripe, with a thin whitish bloom; flesh slightly pulpy, tender, sweet, not quite equal to the Concord. Before it is fully matured it has a very foxy odor, which disappears, to a great extent, later. Vine remarkably vigorous, bealthy and productive; foliage thick and leathery. Ripens with the Concord. This variety is no doubt destined to supply the long-felt want among white Grapes.

\section{Currants}

Fay's Prolific. By odds the best red Currant we have. Large, wonderfully prolific and of good flavor. Has now been fruited here, and is simply grand. It far surpasses all other red varieties, and has fully sustained the broad claims which were made by the disseminator upon its introduction. The bush is a strong grower and comes into bearing early. We regard it as simply marvelous, and all who do not plant it are allowing golden opportunities to pass.

Red Dutch. Larger than the common red, and clusters much larger and less acid. One of the best red Currants.

White Grape. The best white Currant. Bunch moderately long; berries large; very productive; less acid than the red Currants; fine for the table.

\section{Gooseberries}

Downing. A scedling of the Houghton. An upright, vigorous-growing plant. Fruit larger than its parent; color whitish green; flesh ratlier soft, juicy, very good. Productive.
Houghton's Seedling. Rather small; pale red; flesh tender, juicy, sweet and pleasant; produees enormous crops, free from mildew; most profitable market variety.

\section{Blackberries}

Erie. (lained to be as hardy as Snycler, as vigorous as Kittatinny; very productive, free from rust or double blossoms, good quality, round in form, as large as Lawton, and ripens between Farly Harvest and Wilson Junior.

Smith's Improved (Aneient Briton). One of the best of the hardy varieties. Very vigorous, healthy and hardy; fruit-stems loaded with good-sized berries of fine quality that carry well to and feteh highest price in market. For general planting for home or market in all sections subject to severe winters.

Wilson Junior. Continues to vield cnormons crops of large fruit. It combines many good qualities,-size, earliness and productiveness. C'anes are also hardier than the old Wilson, having withstood the winters for four years without injury, unprotected. Its capacity for viclling is extraordinary. The fruit in all respects, both as regards appearance and marketing properties, fully equals its parent. 


\section{Raspberries}

\section{FIRST CLASS-RED}

Brandywine. This variety gives universal satisfaction as a hardy plant and an abundant yielder; berries so firm that they can be shipped eight hundred to a thousand miles. The best of the old varieties of red berries.

Cuthbert (Queen of the Market). Canes tall and vigorous; berries large, conical, rich crimson and very handsome; best quality and carries well; very productive.

Queen of the Market. A very large, productive bright red Raspberry, firm, sweet and delicious. Strong grower. About the best red for family purposes.

\section{SECOND CLASS-BLACK}

Gregg. The largest, handsomest, best and most productive hardy blackeap, fully one-half larger than Mammoth Cluster. Its firmness is one of its good qualities. Another good point, one that will be appreciated by large growers, is its disposition to hang on the bushes, if not gathered when ripe, until perfectly dry. Then, again, their large

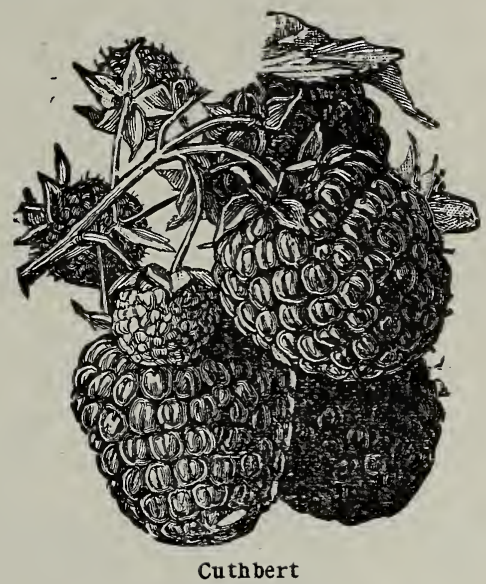

size and firmness enable them to be gathered rapidly, thereby being one of the most profitable varieties. Pickers prefer gathering them at one cent a quart than other varieties at a greater price.

\section{Strawberry Plants}

The ordinary runners are set out in March, April, September, October and November

\section{POT-GROWN STRAWBERRY PLANTS}

\section{Ready for shipment after July 15}

Of late this kind of plant has become very popular, and is almost exclusively employed for garden planting. The failures are few, and much care and labor are avoided. I grow the plants in pots, and when they are well established and ready to ship I turn them out of the pots, preserving the balls of earth around the roots and wrapping them in paper. In this way, during the hottest weather in July, August and September, plants can be transported safely and transplanted satisfactorily. Plants set out in July, August and Setpember will yield a crop next season. These cannot be sent by mail.

Bismarck. Has now been generally tested and its claims quite well sustained by reports from all parts of the country. Its characteristics are thus given in Green's "Fruit Grower": "This is a self-fertilizing Strawberry, possessing all the desirable peculiarities of Bubach No. 5. To those familiar with Bubach nothing further need be said, since Bubach has been a favorite berry, and more plants of it have been planted than of any other. Bubach had two defects which Bismarck corrects. Bubach is pistillate, requiring other varieties to be planterl near it, while Bismarck is self-fertilizing. Bubach, while of good quality, is not of the highest character. Bismarck is of better quality.' $\$ \overline{0}$ per 100.

Gandy. The best late Strawberry yet introduced, and the leading late variety with fruit-growers all over the country. In size and firmness it is all that can be desired; a good grower, with berries large, very uniform, bright crimson color, handsome and showy, firm and of good quality. With good soil and good culture it cannot be excelled as a late berry. Succeeds everywhere, and should have a place in every Strawberry bed. We can supply our customers with fine plants. $\$ 3$ per 100 . 
Haverland. Perfect, makes a good supply of plants and holds the fruit well up from the ground. The berry is from medium to large size, bright red, long and pointed. Fair in quality and a good shipper. It should be well pollenized with perfect bloomers, thus increasing the firmness. It is one of the most productive varieties grown. The season of ripening is medium; it ripens here about May 25. \$3 per 100 .

Jesse. This berry plant was originated at the Somerset Fruit and Plant Farm. It was sent out for the first

kept thinned for best results. The berry ripens with the earlicst, all over at one time, and holds to a good size through the season; firm and productive, of a deep red color. It does well on light and heavy soils.

Nick Ohmer. This plant is faultless, a strong grower, and makes fruit-stems very large, that hold the fruit well up from the ground; it, therefore, does not need mulching. When perfectly ripe it is of a beautiful carmine color, and when packed in crates it is very attractive. An excellent shipper and will surely suit the fancy trarle. I3erries run in size from large to very largest, ancl will alway's command a high price when fancy stock is desired. The flavor is delicious. Ripens about May 20 and continues for about three weeks. The man who does not plant this variety will make a mistake. $\$ 3$ per 100.

Pride of Cumberland. Especially to be noted is the remarkable uniformity of this berry and the great number of large berries which it is capable of producing. When to this is adderl a gooul plant, good quality anı] firmmess, we have indeed a great market berry. $\$ 3$ per 100 .

Senator Dunlap. The originator was so delighted with this variety, thought it so superior to all others, that he named it for the

time in 1897. Its blossoms are perfect, and it is one of the very best pollenizers for pistillate varieties. The berries are large and perfect in form. They are large and uniform in size through the season. The color is of a rich crimson, the flesh brightly colored through and through and of good quality. The plants are vigorous and luxuriant growers. The berry is firm, and will stand shipping to distant markets. Season of ripening, early to medium. \$3 per 100 .

Johnson's Early. This berry is a seedling of the IIof'man and the Creseent. It is perfecetly healthy an. is believed to be absolutely rust-proof. It makes runners freely. It must be biggest man he knew. It is a heavy and never-failing bearer of exquisitely beautiful, deliciously flavored berries. Plant growth rampant. \$t per 100 .

Sharpless. An old standard variety. One of the very largest; when planted on strong, rich, moist soil one would be surprised at the fine specimens it will produce. This variety will do fairly well in lighter soils, but not so well as a variety like Tennessee Prolific on poor soils. The berry when not fully ripe is a little white at the tip. There have been numerous rarieties of this type put out in the past fow years with the claim that it ripens all over, and for this reason only they were 
superior to Sharpless, but I fear they have missed it, as we find when it comes down to actual facts there are but few of this type that will surpass it. $\$ 3$ per 100 .

Wm. Belt. This is a new variety of great merit. It certainly has qualities that commend it most highly; it is pro- ductive and whenever tested is conceded to be most valuable. Twelve berries have filled a quart box, and they are not only large, but beautiful and of highest quality. They color all over and are as red and glossy as any in cultivation, as firm as other berries. $\$ 3$ per 100 .

\section{Asparagus}

To prepare a bed, dig the soil deep and incorporate in it a heavy coat of rotten manure or well-decomposed compost. Plant the roots in rows three feet apart, and one foot between the roots, about three or four inches deep. Cover the berl in the autumn with manure and fork it under in the spring.

Barr's Mammoth. New Asparagus. Originated by Crawford Barr of Pennsylvania; enormous size, tender and sweet. We have a sample in jar in our office which we eut last summer. Very productive.

Conover's Colossal. A variety universally acknowledged to be an improvement on the older sorts on account of its immense size, and being remarkably tender and high flavored. It is claimed that it can be cut one year sooner than other varieties.

Donald's Elmira. This fine, new variety produces thick, green stalks of the finest quality and has recently become very popular. It is also called Vick's Mammoth. This is undoubtedly the largest and best Asparagus grown. In size, color and yield it far surpasses any other variety in cultivation, while we find it to be less susceptible to disease than any other. No one should fail to try this valuable variety.

Palmetto. Of southern origin, a variety of excellent quality, early, very large, very prolific, and all who have used it pronounce it very fine.

Giant Argenteuil. This variety was originally a selection from imported French Argenteuil stock, but has been both acclimated and improved, and is much superior to the original stock. It has been grown for several years, by some of the leading and most successful truckers, near Charleston, S. C., and is pronounced superior to Palmetto, or any other variety in earliness, productiveness, and size of stalks producerl. One large Southern grower speaks of this variety as follows: "I have been growing Asparagus for 30 years, and have grown both Palmetto and Argenteuil, and there is as much difference between them as there is between Conover's Colossal and Palmetto. And from my personal experience of Conover's Colossal and the Palmetto, the Palmetto is twice the size of Conover's Colossal and longer lived. And I consider Argenteuil twice the size of Palmetto, earlier,

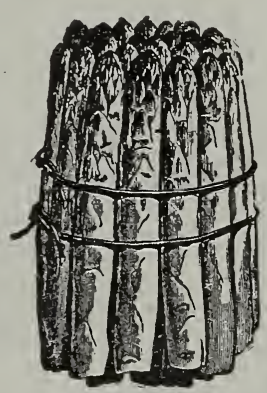
more prolific, and longer lived. Last season I could not near fill all the orders I received for this popular variety, notwithstanding I had a large supply.",

\section{Rhubarb}

The large size, fine texture, and superior quality of this new variety over the old cultivated "Pie Plant," cannot be conceived by those who have never grown it.

We have frequently grown stalks, with ordinary cultivation, as thick as a man's wrist, and from three to four feet in length; no plant is more benefited by a heavy coat of strong, rich manure.

The plants should be set four feet apart each way, and the stalks will be fit for use the second season after planting.

Myatt's Linnaeus. This is, without doubt, the best variety in cultivation; stalks long and heavy, without being in the least stringy or tough, with a mild subacid flavor. 


\section{ORNAMENTAL DEPARTMENT}

You will find our Ornamental Department interesting, especially in the shrubbery nursery, which contains rare specimens from all parts of the world, lately imported. Our evergreens are grown in stift clay, which causes them to make plenty of fibrous roots.

\section{Deciduous Trees}

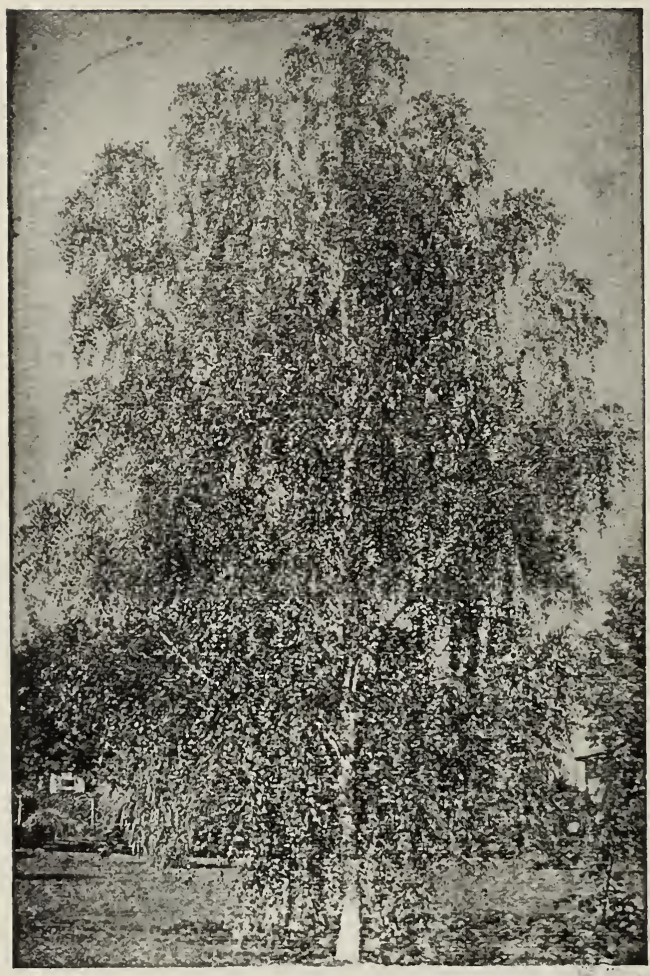

White Birch

ASH. Fraxinus

American White (F. Americana). A good-sized tree with straight trunk and light, airy foliage. Does well in almost all situations.

European. (F. excelsior). A lofty rapid-growing tree of great value. It is well adapted for avenue or street planting.

\section{BEECH. Fagus}

American ( $F$. ferruginea). A large native tree with smooth bark, horizon- tal spreating branches and abundant coarsely tootherl foliage.

European (F. sylvatica). Native of Europe, growing from 60 to 100 feet high; foliage larger and habit more compact than in the preceding.

Purple (F. purpurea), Discovered in a German forest. An elegant vigorous tree, growing 40 to 50 feet high; the foliage in spring is deep purple, and later in the season changes to crimson, and again to a dull purplish green in the fall.

Rivers' Smooth-leaved Purple (F. purpurea Riversi). This variety, which we procured of Mr. Rivers, differs from the preceding by its compact symmetrical habit of growth and crimson foliage early in the spring, changing to a dark purple in summer. The finest of all purple-leared trees.

\section{BIRCH. Betula.}

American White (B. populifolia). The Birches are all elegant and feathery trees too little planted. This species is a rapid grower, and flourishes on poor soils. A good tree to plant with evergreens.

European White (B. alba). Remark-able for its snow-white bark and light and elegant foliage.

\section{CATALPA}

The Catalpas flower in .July, when few trees are in bloom. Their blossoms are large, very showy and quite fragrant; leaves large, heart-shaped and yellowish green. They are all effective, tropical-looking lawn trees.

Chinese (C. Bungei). A species from China, of dwarf habit, growing only from 3 to 5 feet high. Foliage large and glossy; a shy bloomer. Topgrafted on tall stems it makes an effective umbrella-shaped tree. Dwarf trees, $\$ 1 ;$ top-grafted, $\$ 2$. 
Common (C. bignonioides; syn., C srringifolia). Native of the southern states. A showy, rapid-growing, spreading, irregular tree, with very large heart-shaped leaves and prramidal clusters, a foot long, of white and purple fragrant flowers. Blooms latter part of June, when few trees are in blossom and, therefore, very desirable.

\section{CRAB. Pyrus}

TTe invite special attention to the Double-flowering Crabs; their beauty and value seem to have been overlooked and are therefore not appreciated.

Bechtel's Double-flowered American (P. angustifolia). One of the most beautiful of the many fine varieties of flowering Crabs. Tree of medium size, covered in early spring with large beautiful, double fragrant flowers of delicate pink color. From a distance the flowers have the appearance of small roses. A great acquisition, and certain to become very popular as soon as known. Blooms when quite young and bears its beautiful flowers in great profusion.

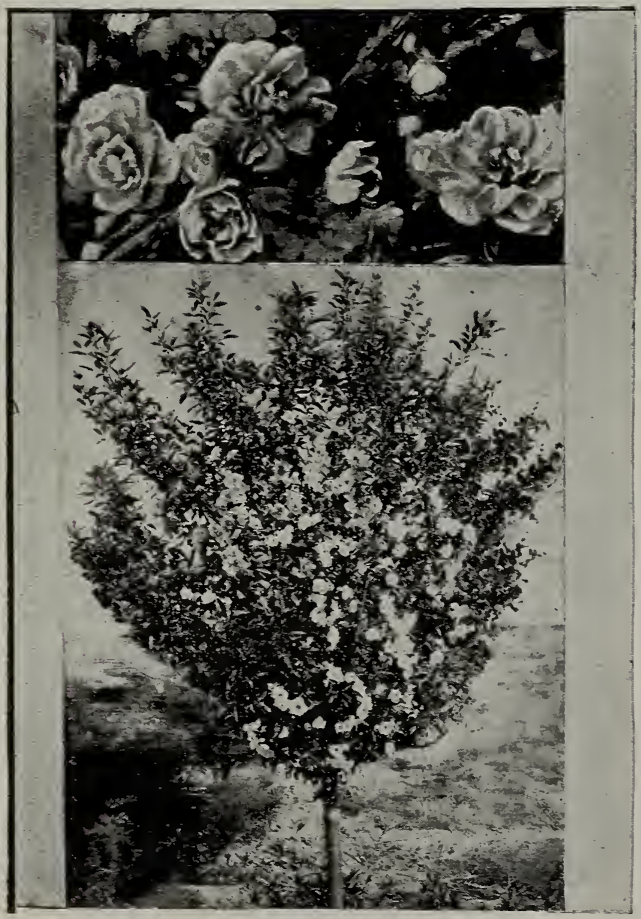

Bechtel's Crab

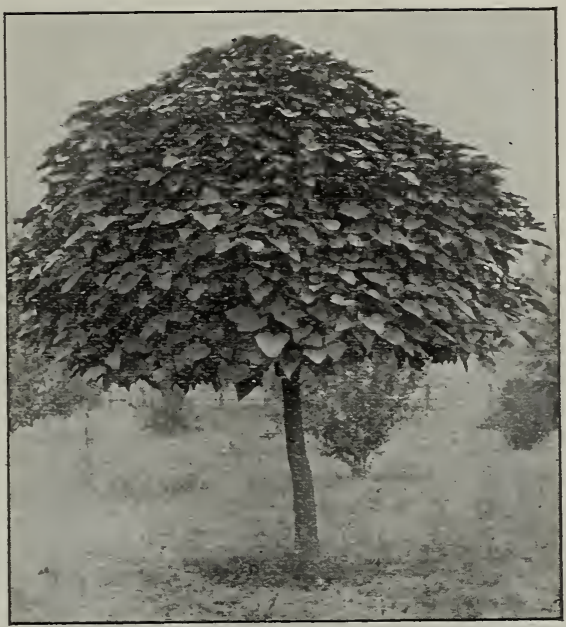

Catalpa Bungeii.

DOGWOOD. Cornus

Large White-flowering (C. florida). A small-sized native tree of great beauty when in bloom. Floral covering large, pure white, followed by brilliant scarlet fruit.

\section{ELM. Ulmus}

American White, or Weeping (U. Americana). The noble spreading and drooping tree of our own forests.

English (U. campestris). An erect, lofty tree, of rapid, compact growth, with smaller and more regularly cut leaves than those of the American, and darker colored bark. The branches project from the trunk almost at right angles, giving the tree a noble appearance.

\section{FRINGE TREE Chionanthus}

White Fringe (C. Virginica). A small native tree or shrub, of roundish form, with large, glossy leaves and drooping racemes of pure white flowers, having narrow, fringe-like petals; blossoms in May or June.

\section{HORSE-CHESTNUT}

\section{AEsculus}

A genus of trees bearing magnificent flowers in great abundance.

White-flowered (AE. Hippocastanum). A beautiful wellknown sort with round dense 
head, dark green foliage, and a profusion of showy flowers in early spring.

Double White-flowered (AE. Hippocastanum alba pleno). A superb variety, with large spikes of double flowers.

Red-flowered (AE. rubicunda). Not as rapid a grower as the White; foliage a deeper green; dwarf-like. The intense color of the flowers makes it very showy.

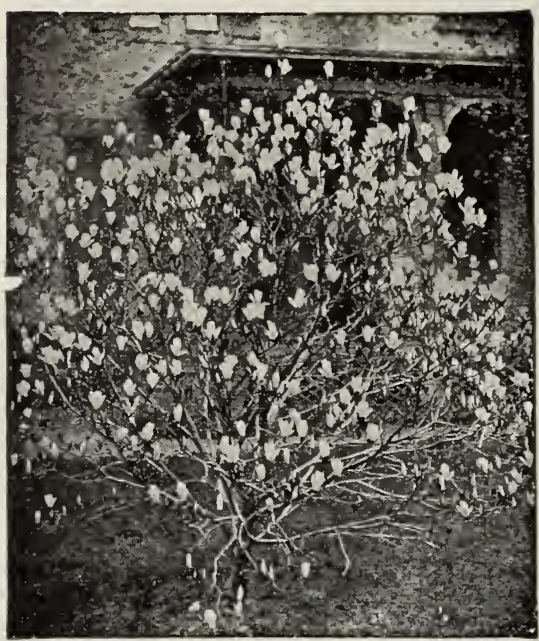

Magnolia

GINKGO, or MAIDENHAIR TREE Salisburia

Japan (S. adiantifolia). A rare and beautiful tree, with pale green, fanlike foliage, of a thick, leathery nature; when pruned it forms a handsome compact head; perfectly hardy.

JUDAS TREE, or RED-BUD. Cercis American (C. C'anadensis). A very ornamental native tree of medium size, irregular rounded form, with perfect heart-shaped leaves of a pure green color, glossy surface above and grayish green beneath. The tree derives the name of Red-bud from the profusion of telicate reddish purple flower's with which it is covered before the foliage appears. Flowering at the same time as the Chinese magnolias, it may be planted aysong them in groups with fine effect. Grown as single specimens they are also beautiful and attractive, and deserve to be classed among our finest ornamental trees.

Japan (C. Japonica). Of medium size. rounded form; foliage deep shining green and heart-shaped; flowers larger than those of the American, and of a rich reddish purple color. A valuable addition to the list of choice small trees.

\section{LABURNUM. Cytisus}

Golden Chain (L. vulgare). A small tree with long, compound leaves of shining green, with smooth, bronzy bark, producing, in June and July, drooping clusters, a foot long, of the brightest golden yellow blossoms of sweet-pea shape and size. One of the most beautiful of all small lawn trees.

\section{LINDEN. Tilia}

American, or Basswood (T. Americana). A rapid-growing, beautiful native tree; with very large leaves and frag. rant flowers.

European (T. Europea). A very fine pyramidal tree, with large leaves and fragrant flowers.

\section{MAGNOLIA}

Cucumber Tree (M. acuminata). A noble, beautiful tree, with large leaves and yellow flowers, tinted with bluish purple.

Chinese Purple. A dwarf species, with showy purple flowers in May or June.

Lenne's Magnolia (M. Lennei). A seedling of M. purpurea. Foliage large; flowers dark purple. A superbvariety.

M. semperflorens. A new seedling; color deep purple; in flower nine months during the vear. "A most excellent acquisition.

Umbrella Tree (M. tripetela). A smallsized tree, with immense leaves and large white flowers \pm to 6 inches in diameter.

\section{MAPLE. Acer}

Ash-leaved, or Box Elder (A. Negundo). A rapid grower with leaves and young branches of a bright green; exceedingly ornamental.

English, or Cork-barked (A. campestre). From central Europe. Forms smallsized tree, with rough corky bark and a regular rounded outline; leaves small, five-lobed and numerous. Fine for the lawn.

Norway (A. platanoides). One of the most valuable ornamental trees for the lawn; broad, rich, dark green foliage, and of compact, globular form. 
Schwedler's Norway (A. platanoides Schwedleri). Purple-leaved Norway Maple. A new, distinct, conspicuous variety, with bronze-red or purple foliage.

Scarlet (A. rubrum). A rapid-growing tree, with red flowers very early in spring. Valuable for street and park planting.

Silver-leaved (A. dasycarpum). Of exceedingly rapid growth, and desirable for immediate effect.

Sugar, or Rock (A. saccharinum). A very popular American tree, and for its stately form and fine foliage, justly ranked among the very best both for the lawn and avenue.

Sycamore (A. Pseudo-platanus). A European species of medium size, with very dark green leaves; growth rapid.

Wier's Cut-leaved (A. dasycarpum Wieri laciniatum). A variety of the Silver-leaved Maple. A rapid-growing tree with slender branches and very pretty indented leaves, silvery on the under side. One of the best lawn trees.

\section{JAPANESE MAPLE}

Cut-leaved Purple (A. Polvmorphum dissectum atropurpureum). Dwarf, weep-

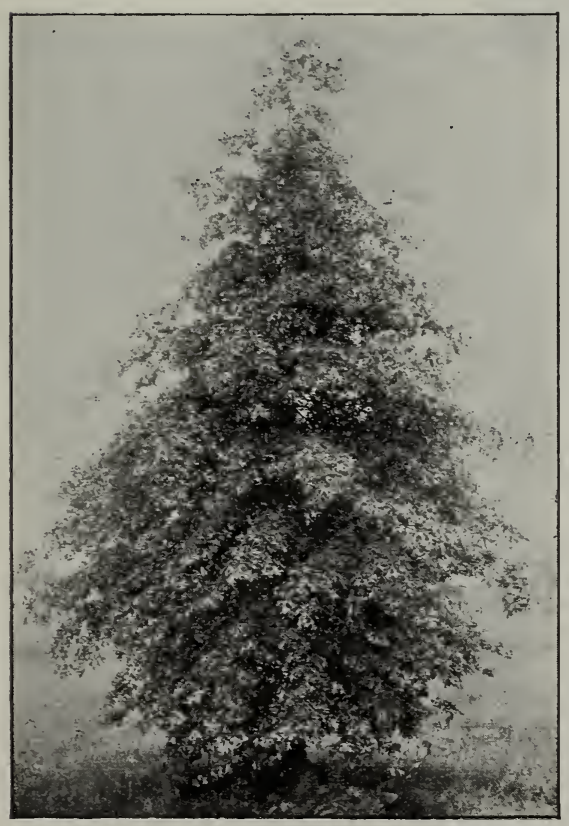

Pin 0ak.

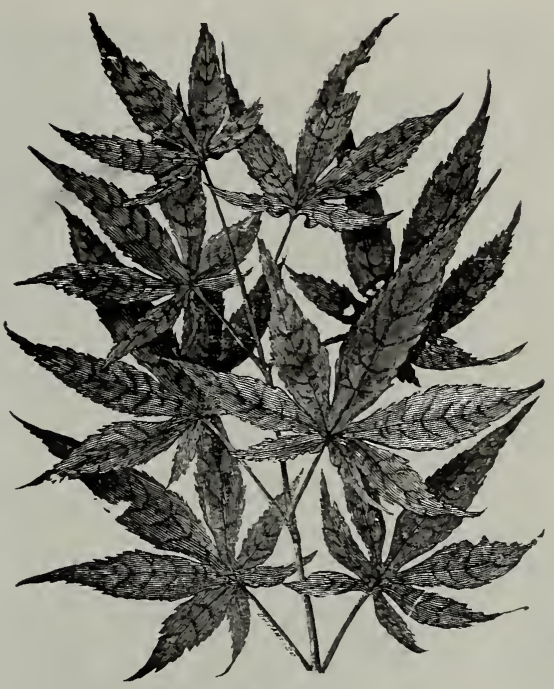

Japanese Maple.

ing, graceful form; branchlets crimson; leaves deeply and finely cut into shred-like divisions, of a beautiful rose-color when young, changing to a deep dark purple. Choice and ornamental variety,

Various-colored (A. versicolor). Good grower compared with others. Foliage similar to that of its parent, A. polymorphum; spotted irregularly and picturesquely with pink, white and green. A choice and most interesting varięty.

Dark Purple-leaved (A. polymorphum atropurpureum). Forms a bushy shrub; foliage dark purple and deeply cut. Very ornamental.

\section{OAK. Quercus}

Pin (Q. palustris). One of the quickest growing of the Oaks, reaching a height of 60 feet, and forming a desirable addition to the park. Generally regarded as one of the best of the Oak family.

Turkey (Q. Cerris). A large vigorousgrowing species from the south of Europe.

\section{POPLAR. Populus}

Carolina (P. angulata). A poplar with large shining green leares, which are very handsome; a very rapid grower, bearing transplanting unusually well; is free from attacks of worms. and is suitable for watering places on the seacoast, where maples will not always thrive. 


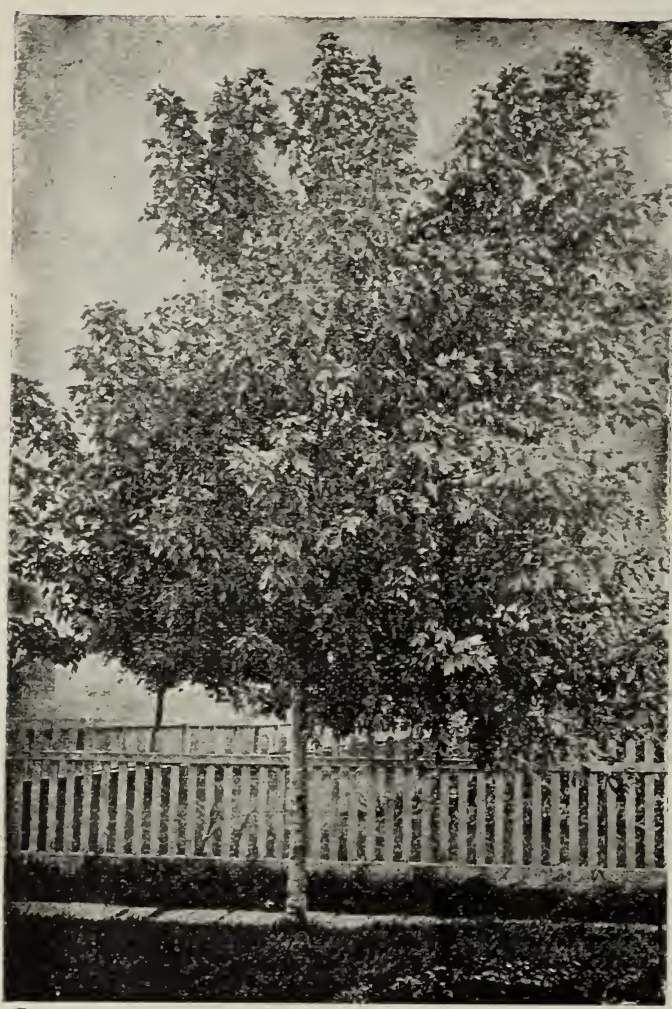

Silver Maple

Lombardy (P. fastigiata). Fifty to 60 feet. The tall pyramidal growth of this one has made it well known everywhere, and very useful in many situations. The leaves are very small and nearly round. A group of these on the lawn produces a most striking effect. Can be used as a street tree when one of narrow growth is required. At Newport it is planted thickly in the form of a tall herlge, and in this way acts as a useful sereen to shield the house from the stables or any other objectionable object.

\section{PRUNUS}

European Bird Cherry (P. Padus). A rapid-growing, beautiful tree, with glossy foliage and long bunches of fragrant white flowers in May, succeeded by cluster's of fruit-like black currants.

P. Pissardi. A new purple-leaved Plum from Persia. The fruit is mediumsized, nearly round; dark purple; flesh pulpy, very sweet; juicy and good.
SWEET GUM. Liquidambar

Bilsted (L. styraciflua). A large native tree, with rough, corky bark, and shining, deeply lobed, star-shapeil leaves, changing to deep crimson in the autumn.

\section{SYCAMORE. Platanus}

African (P. latifolia). Rapid growth; spreading habit; enormous leaves, resembling our native Sycamore.

\section{THORN. Crataegus}

Double Scarlet (Crataegus coccinea flore pleno). A tree of fine habit, with rich luxuriant foliage. Flowers unusually large, much larger than the double red, of a deep crimson color, with scarlet shade, and very double. A charming variety.

White Thorn. Has small white flowers. A highly ornamental variety, on account of both foliage and flowers. Makes a striking contrast when planted with the double scarlet.

\section{TULIP TREE. Liriodendron}

Tulip Tree, or Whitewood (L. Tulipifera). A magnificent native tree, of tall, pyramidal habit, with broad, glossy, fiddle-shaped leaves of a light green color, and beautiful tulip-shaped flowers. Allied to the magnolias, and, like them, difficult to transplant, unless of small size.

\section{WILLOW. Salix}

Common Weeping (S.Babylonica). This well-known weeping tree is from Âsia and grows to a large size.

Royal Willow (S. regalis). An elegant tree, with rich, silvery foliage. Very effective in groups.

Rosemary-leaved Willow (S. rosmarinifolia, or petiolaris). When worked five to seven feet high, a very striking and pretty round-headed small tree. Also very desirable in shubberies when worked low. Branches feathery; foliage silvery. Golden Willow (S. vitellina aurantiaca). A handsome tree. Conspicuous at all seasons, but particularly in winter on account of its yellow bark. 


\section{Coniferae (Evergreens)}

\section{ARBORVITAE. Thuja}

American (T. occidentalis). This plant is, all things considered, the finest erergreen for screens. It is very hardy and easily transplanted; it soon forms a most beautiful hedge; rery dense.

Compact (T. compacta). A variety of the Chinese, but more dwarf and compact; perfectly hardy.

Ever-golden ('T. semper aurea). A variety of Aurea; of dwarf habit but free growth. It retains its golden tint the year round. One of the best golden variegated evergreens.

George Peabody. Of dwarf, compact growth; foliage bright golden color, which it retains throughout the summer. The best golden variety.

Hovey's Golden (T. Hoveyi). The foliage of this charming plant is of a bright yellowish green hue, and the form compact and globular. Espeeially fine.

Pyramidal (T. pyramidalis). Of upright, compact habit, like the Irish Juniper. Very desirable.

Siberian (T. Sibirica). Exceedingly hardy, keeping color well into winter; growth compact and pyramidal. Makes an elegant lawn tree.

\section{FIR. Abies}

Balsam (A. balsamea). A very erect, regular pyramidal tree, with dark green somber foliage. Grows rapidly and is very hardy.

Cephalonian (A. Cephalonica). From Europe. A remarkable and beautiful species, very broad for its height. Leaves silvery and dagger-shaped, with a spine on the point. Quite hardy and vigorous.

\section{JUNIPER. Juniperus}

Irish (J. Hibernica). Very erect and tapering in its growth, forming a column of deep green foliage.

Stricta. A dwarf variety; dark green foliage; compact, very handsome. New in this country.

Red Cedar (J. Virginiana). A well known American tree; varies much in habit and color of foliage, some being quite stiff, regular and conical, and others loose and irregular. It makes a fine ornamental hedge plant.

\section{PINE. Pinus}

Austrian, or Black (P. Austriaca). A remarkably robust, hardy, spreading tree with dark green, rigid foliage.

Scotch (P. sylvestris). A fine, robust, rapid-growing tree, with silvery green foliage. Pyramidal shape when young, but round-topped in age.

White (P. Strobus). The most ornamental of all our native Pines; foliage silvery green.

Lofty Bhotan Pine (P. excelsa). A native of the mountains of Northern Inclia. A graceful and elegant tree, with drooping silvery foliage, resembling that of the White Pine, but longer and more pendulous. Hardy and vigorous.

\section{RETINOSPORA}

R. plumosa aurea. One of the most beautiful of the golden evergreens at all seasons of the rear, but espe. cially in summer. When the tree starts to grow in the spring, the young shoots are a rich shade of golden yellow. It is a most valuable aequisition to the list of golden conifers.

Japan Conifer (R. squarrosa). Roundheaded, bushy, covered with numerous small leaves of a whitish green tint, densely branched, curved and gracefully spread.

Golden Retinospora pisifera (C. p. aurea). The free and graceful habit of this tree, with its hardiness and the constancy of its rich yellow hue, make it one of the best golden evergreens in cultivation.

C. P. filifera; syn., (Retinospora filifera). An odd tree, with gracefully pendulous, thread-like branches.

\section{SPRUCE. Picea}

Norway (P. excelsa). A lofty, elegant tree, of perfect pyramidal habit, remarkably elegant and rich, and as it gets age has fine, graceful, pendulous branches. Tery popular, and deservedly so. One of the best evergreens for hedges.

White American (P. alba). A tall tree, with loose, spreading branches and light green foliage.

Hemlock, or Weeping (P. Canadensis). A very elegant and graceful tree, with fine form, pendulous or drooping branches, and delicate or dark 
green foliage. Makes a beautiful lawn tree or ornamental hedge.

\section{YEW. Taxus}

English ('T. baccata). A large bush or tree. It is densly branched and can be trimmed into any shape.

\section{HEDGE PLANTS}

American Arborvitae,

Box Edging,

California Privet,

Norway Spruce,

Osage Orange.

\section{Evergreen Shrubs}

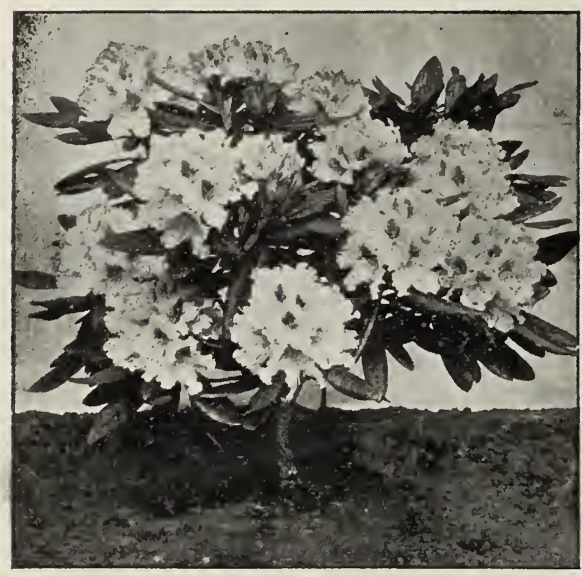

Rhododendron

Holly-leaved (M. aquifolium). A beautiful holly-like shrub, with erect racemes of golden yellow flowers.

\section{Box. Buxus}

Common Tree (B. sempervirens). From England. A handsome shrub, with deep green foliage.

Dwarf. The well-known sort used for edging.

\section{EUONYMUS}

E. aurea. Each leaf is dark, waxy green, with broad markings of golden yellow, also often ribbed and veined with gold; each branch is densely clothed with this eharming foliage, and it is, all in all, a shrub of rare beauty.

Japan (E. Japonicus). Hardy in proteeted situations. Leaves leathery and glossy.

Silver Variegated (E. argenteus). Foliage distinctly marked with white.

Trailing (E. radicans). A dwarf, vinelike plant, with evergreen leaves.

\section{LAUREL. Kalmia}

American, or Mountain (K. latifolia). Calico Bush. A beautiful nativo evergreen shrub, with shining foliage and dense clusters of pink or nearly white flowers in spring. Requires same treatment as the rhododendron.

\section{RHODODENDRON}

The Rhododendrons are magnificent evergreen shrubs. All prefer a peaty soil and somewhat shaded situation. The Catawbiense varieties are the most hardy, and succeed better in our cli-

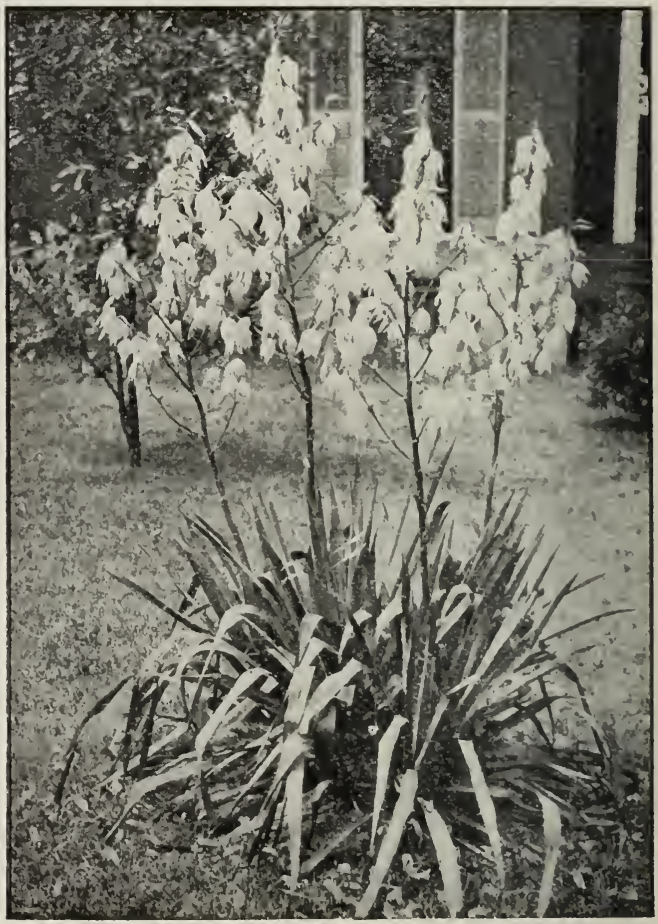


mate than any other. In this latitude they require to be protected in winter.

Great Laurel (R. maximum). An evergreen shrub, 5 to 30 feet high, with dark green leaves 4 to 10 inches long; flowers white, pink or purple, greęnish in the throat and spotted with yellow or red. Takes readily to cultivation.
THORN. Crataegus

C. Lalandii. A variety with larger leaves than the type. Very pretty.

\section{YUCCA}

Thready Adam's Needle (Y. filamentosa). A tropical-looking plant, with long, narrow leaves; the flower stalk rises from the center, bearing numerous creamy white, bell-shaped flowers.

\section{Deciduous Shrubs}

\section{ALMOND. Prunus}

Dwarf Double White-flowering (P. Japonica alba flore pleno). Produces beautiful double white flowers in May.

Dwarf Double Red-flowering (P. Japonica rubra flore pleno). A beautiful small shrub, bearing red flowers in May.

\section{ALTHEA. Hibiscus}

A. frutex (H. Syriacus). Rose of Sharon. Very desirable on account of blooming in the autumn months. Double White, Double Purple, Double Red.

Totus albus. Moderate grower, free bloomer; flowers single, pure white and of good substance. The finest single white Althea.

\section{AMORPHA}

Indigo Shrub (A. fruticosa). Six to $T$ feet. This is a large growing species, forming a good-sized, spreading bush. The indigo-colored flowers are in finger-like spikes, three or more spikes in a cluster. They expand the first week in June. It is used largely for massing in parks and on large estates.

\section{ARALIA}

Angelica Tree (A. Japonica). A handsome and distinct shrub from Japan, with large tripinnate leaves and spiny stems; flowers white, in large spikes, in September. This species forms small trees and is very useful to give a tropical appearance to gardens. They require slight protection with straw or evergreen boughs in winter.

\section{AZALEA}

A. mollis. A splendid hardy species from Japan, and one of the most valuable flowering shrubs. Flowers

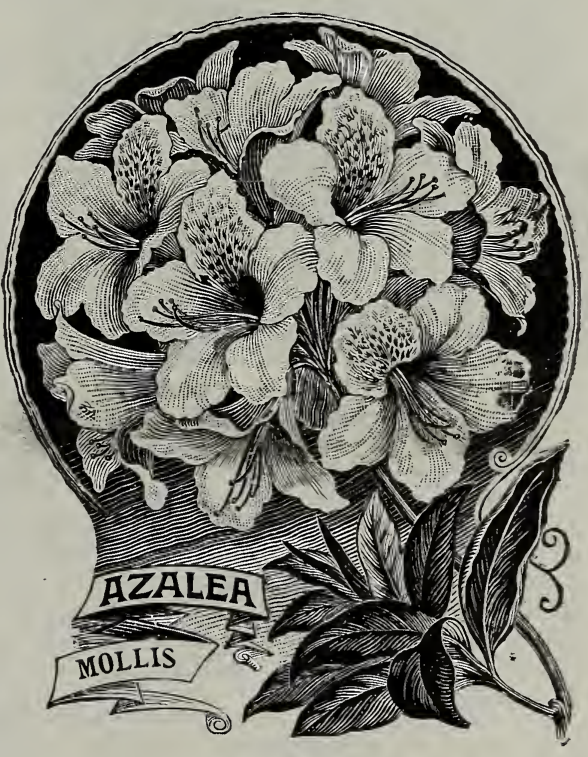

large and showy, like those of the rhododendron, in fine trusses and of various colors. Choice seedling varieties.

Pontic (A. Pontica). Ghent varieties. Native of Asia Minor. A species growing 3 to 4 feet high, with small hairy leaves and yellow, orange and red flowers. The Ghent hybrid varieties which we offer combine nearly all colors and possess a delightfu] perfume. They rank next to the rhododendron for the decoration of lawns and pleasure grounds. The blooming season continues through the months of May and June.

\section{BARBERRY. Berberis}

Purple-leaved (B. folia purpurea). Valuable for its rich, dark purple foliage; flowers showy. 


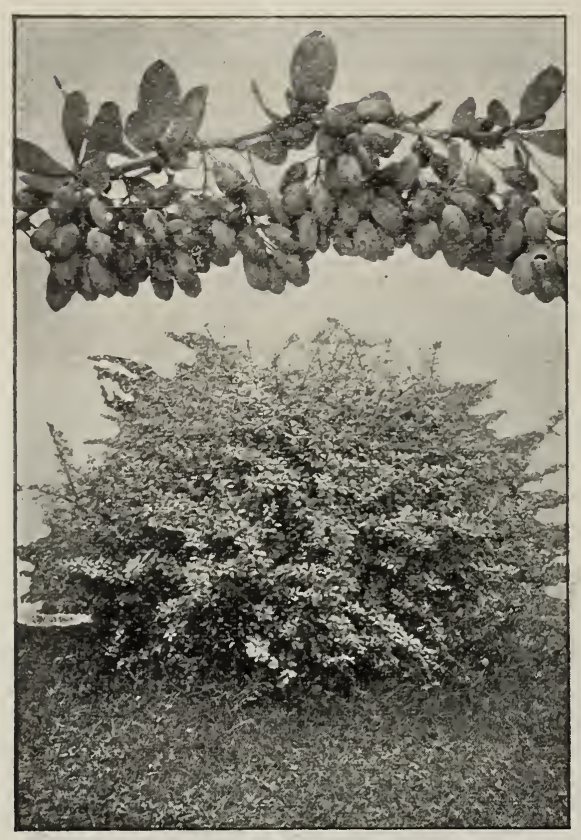

Thunberg's Barberry

European Barberry (B. vulgaris). A handsome deciduous shrub, with yellow flowers in terminal drooping racemes in May or June, followed with orange scarlet fruit.

Thunberg's (B. Thunbergii). From Japan. A pretty species, of dwarf habit; foliage small, changing to red in autumn.

\section{COLUTEA}

Bladder Senna (C. arborescens). Native of the south of Europe. A large shrub, with small, delicate foliage, and yellow, pea-blossom shaped flowers in June, followed by reddish pods or bladders.

\section{CARYOPTERIS}

Blue Spiraea (C. mastacanthus). A pretty autumn blooming shrubby plant, producing clusters of beautiful blue fragrant flowers in great profusion from September until frost. Dies to the ground here in winter.

\section{CALYCANTHUS}

Smooth-leaved (C. loevigatus). Sweetscented Shrub, or Allspice. A favorite shrub, with fragrant wood and flowers of rich chocolate color.

\section{CLETHRA}

White Alder. Sweet Pepper Bush. Scheineller, Ger. (C. alnifolia). Spikes of clear white fragrant flowers in Angust.

\section{DOGWOOD. Cornus}

Red-branched (C. sanguinea). A native species. Very conspicuous and ornamental in winter, when the bark is blood-red.

\section{DEUTZIA}

D. crenata fl. pl. Similar in growth and habit to C. gracilis. Flowers double, white, tinged with rose. The finest flowering shrub in cultivation.

Double White-flowering (D. candidis sima). A snow-white flower, that is especially beautiful, as well as valuable for bouquets, baskets, etc.

Rough-leaved (D. scabra). Beautiful, profuse-flowering shrub; white.

Slender-branched (D. gracilis). A charming species, introduced from Japan by Dr. Siebold; flowers pure white.

Pride of Rochester. Double pure white.

\section{ELAEAGNUS. Longipes}

Japan Oleaster. From Japan. In July the plant is covered with bright red berries of large size and edible, the flavor being pungent and agreeable. Laden with fruit the bush is highly ornamental, and the fact that the leaves remain fresh till late in the autumn gives it additional value for garden decoration. Destined to widespread popularity as soon as known.

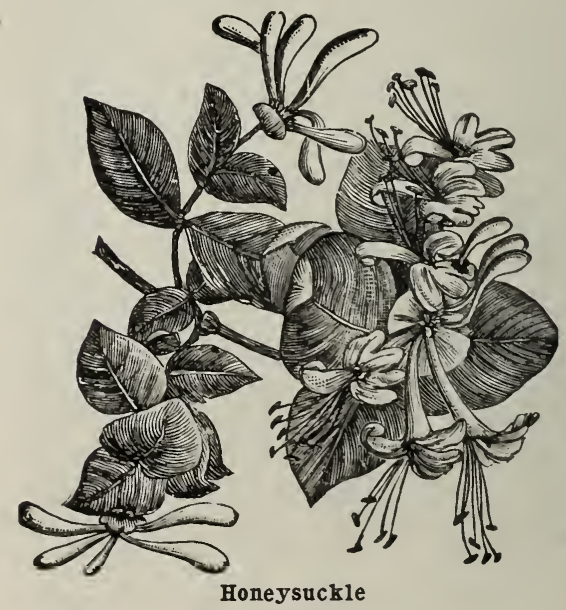




\section{EXOCHORDA}

E. grandiflora. From North China. A fine shrub, - producing large white flowers in May. Difficult to propagate; scarce.

\section{EUONYMUS}

Burning Bush (E. Europaeus). Spindle Tree; Strawberry Tree. A very ornamental and showy shrub. Its chief beauty consists in its brilliant berries, which hang in clusters from the branches until midsummer.

\section{FILBERT. Corylus}

Purple-leaved (C. purpurea). A ver conspicuous shrub, with large dark purple leaves.

\section{FORSYTHIA}

Golden Bell (F. viridissima). Leaves dark green; flowers bright yellow, very early in the spring.

Weeping Golden Bell (F. suspensa). A beautiful shrub, with drooping branches; flowers yellow and quite showy.

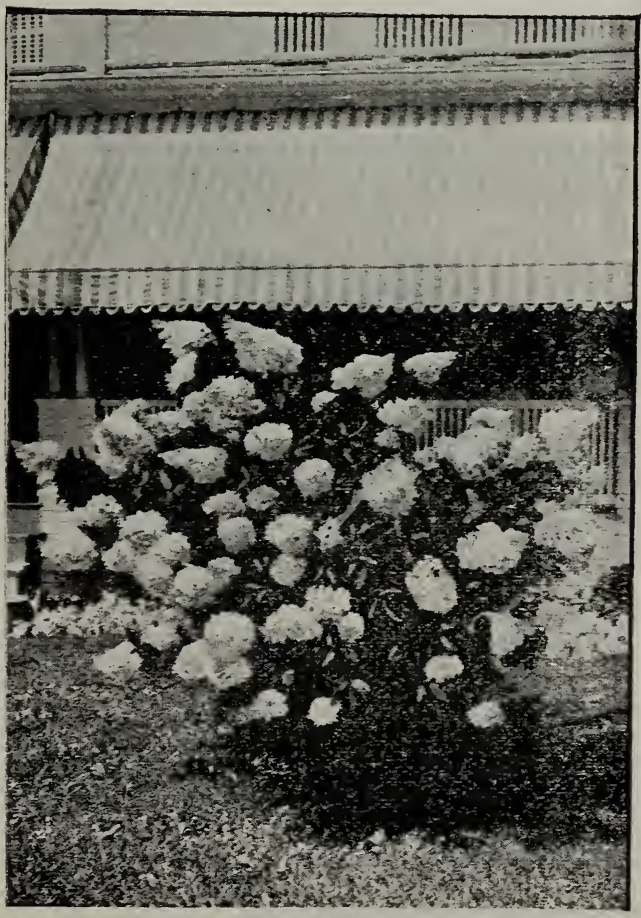

Hydrangea

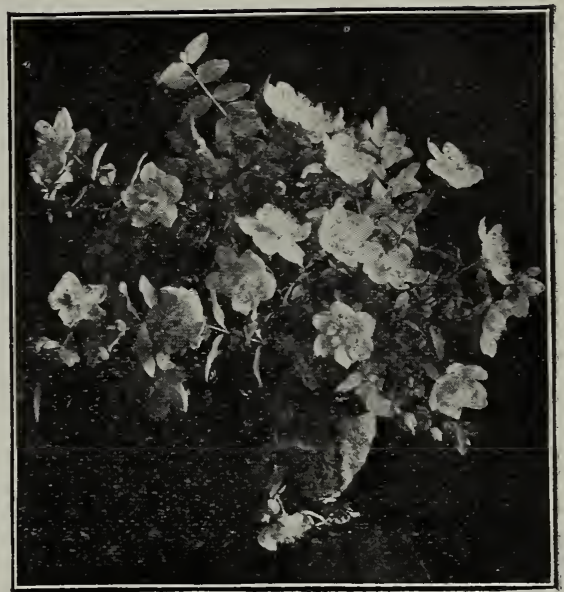

Hypericum Moserianum HONEYSUCKLE. Lonicera

\section{Upright, or Tree}

Fragrant (L. fragrantissima). A spreading shrub, with deep green foliage and very fragrant small flowers, which appear before the leaves; foliage almost evergreen. Most desirable.

L. grandiflora alba. A variety of upright habit, with large, pure white flowers. Fine.

L. Alberti. Violet bell-shaped flowers; leaves narrow. Hardy variety; somewhat creeping.

Ledebour's (L. Ledebouri). From California. A distinct species, with red flowers in May.

L. Morrowii. A fine variety from Japan. Valuable for its pretty rest fruit.

Pink-flowered. (L. grandiflora). A beautiful shrub; very vigorous and producing large, bright red flowers, striped white, in June.

Tartarian (L. Tatarica). Pink flowers which contrast beautifully with the foliage. This and Grandiflora appear to fine advantage planted together. June.

White Tartarian (L. alba). Forms a high bush, with fragrant creamy white flowers. May and June.

\section{HYDRANGEA}

H. paniculata grandiflora. Large panicle-flowered Hydrangea. A fine shrub; flowers white, in great pyramidal panicles, and produced in $\mathrm{Au}$ gust and September, when very few shrubs are in flower. One of the finest flowering shrubs. 


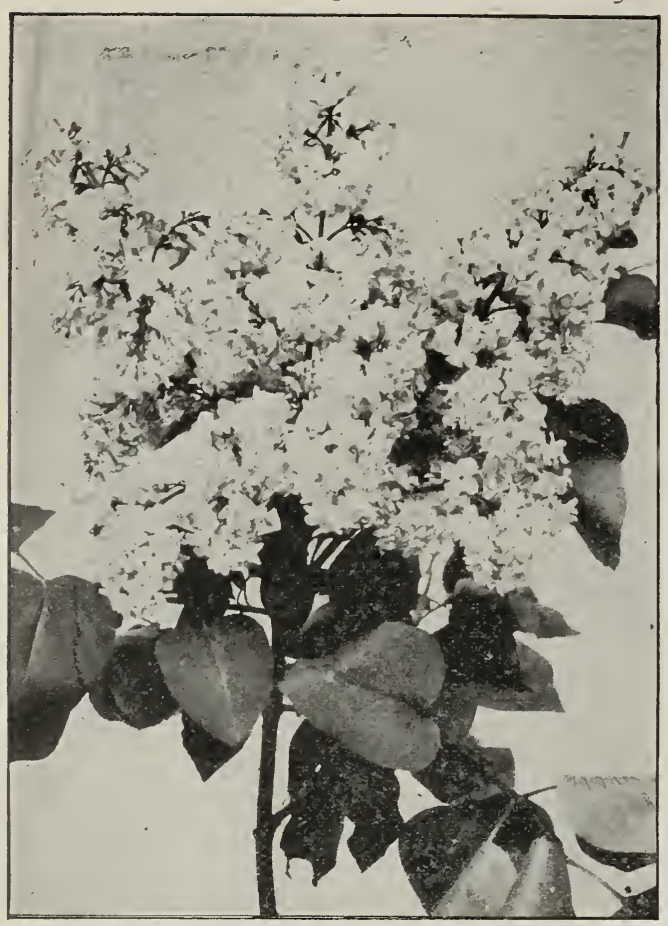

Lilac

\section{HYPERICUM}

Moserianum. A charming shrub of dwarf habit, producing large single yellow flowers in great profusion during the summer.

\section{KERRIA. Corchorus}

Japan (C. Japonica). A slender, greenbranched shrub, 5 to 6 feet high, with globular yellow flowers from July to October.

\section{LILAC. Syringa}

Common (S. vulgaris). Bluish purple flowers. A standard variety. Always good.

Common White (S. alba). Cream-colored flower's.

Ludwig Spath. This is, without doubt, the most beautiful variety of the old purple Lilac ever yet produced. The single blossoms, as well as the clusters, are very large, and of splendid lark purple-red color, not only as buds, but even when the blossoms are fully expanded. This handsome variety was obtained at the celebrated nursery of Ludwig Spath, the best nursery of Germany, by raising and flowering 15,000 seedlings from seed of the choicest varieties.

Marie le Gray. Large panicles of white flowers. A new variety of great merit.

Rothomagensis. A distinct hydrid variety, with reddish flowers; panicles of great size.

\section{ORNAMENTAL GRASSES}

Eulalia Japonica Zebrinus. This fine ornamental grass is the finest of all Eulalias for single lawn species or clumping. It grows 4 to 7 feet high; perfectly hardy, needs no protection during winter and greatly improves with age. The leaf-blades are deep green, distinetly striped crosswise with large bars of pure white. We had on our trial grounds, as late as November 1, thousands of Japonica zebrinus with 50 to 100 plumes on single clumps. All our plants are propagated from the root, and hence more valuable than seedlings, which do not eołne true.

E. Japonica variegatus. A standarcl old sort of distinctive value; blades are striped lengthwise in a handsome manner, being a combination of creamy white in the center with a broad margin of bright green. Plumes are very beautiful.

Erianthus Ravennae. An entirely hardy reed-like ornamental grass, throwing up 30 to 40 fine, ereet flower-stalks 8 to 10 feet high the first season.

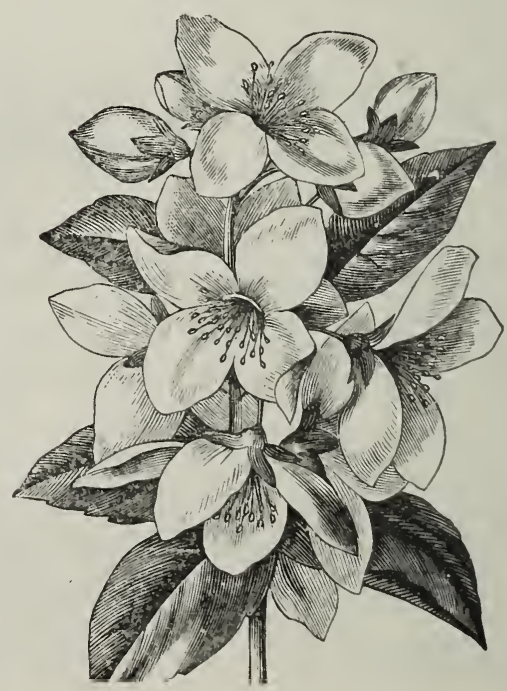

Syringa 
The plumes are soft gray in color and highly valued as parlor ornaments. Very effective as lawn plants.

\section{PLUM. Prunus}

P. Pissardi. The finest purple-leaver small tree or shrub of recent introduction. The young branches are a rery dark purple, and retain this beautiful tint till they drop late in autumn; no other purple-leared tree or shrub retains its color like this. Plants easily and is worthy of wide dissemination.

\section{PURPLE FRINGE. Rhus}

Smoke Tree (R. Cotinus). A very much admired and conspicuous shrub or small tree, covered in midsummer with a profusion of dusky fringelike flowers.

\section{PRIVET}

California (L. ovalifolium). A vigorous, hardy variety of fine habit; foliage nearly evergreen; grows well in almost every soil. Ornamental and one of the best hedge plants.

\section{PHILADELPHUS. Mock Orange (SYRINGA)}

Garland Syringa (P. coronarius). A well-known shrub, with highly scented, pure white flowers. One of the first to flower.

Golden-leaved Syringa (P. folius aureus). One of the most satisfactory and popular shrubs, with golden-tinted foliage.

Large-flowered Syringa (P. grandiflorus). Has very showy, large flowers, slightly fragrant; branches somewhat straggling.

\section{PRUNUS. Plum and Almond.}

Dwarf Double White-flowered Almond. P. Japonica flore albo pleno. (Erroneously Amygdalus pumila alba.) Produces beautiful double white flowers in May.

Dwarf Double Red-flowered Almond. P. Japonica flore rubro pleno. (Erroneously Amygdalus pumila.) A beautiful small shrub, bearing in May, hefore the leaves appear, an abundance of small, double, rose-like flowers, closely set upon the twigs.

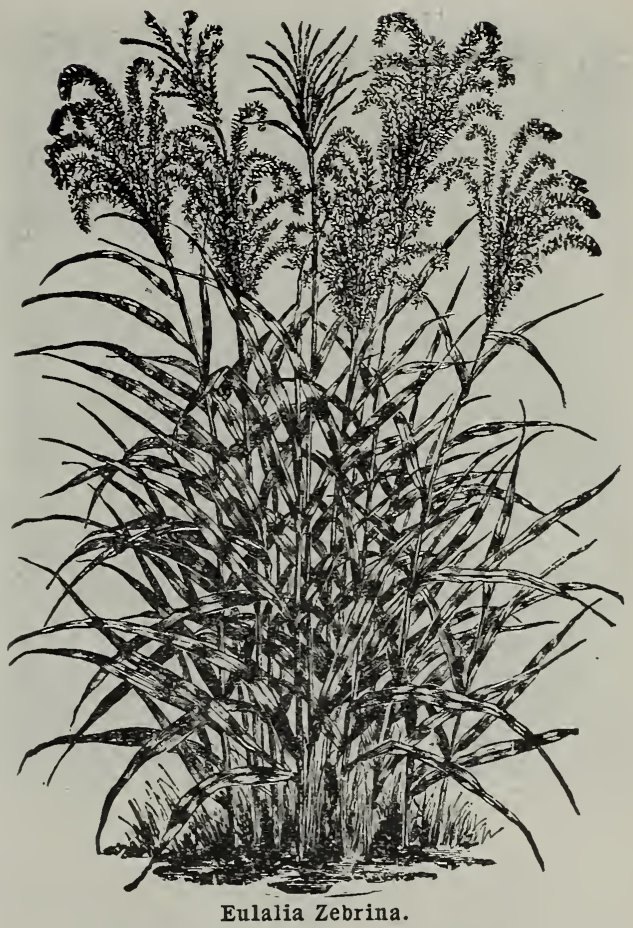

JAFAN QUINCE. Cydonia

Scarlet (C. Japonica). Has bright scarlet-crimson flowers in great profusion in the early spring. One of the best hardy shrubs in the catalogue.

\section{RHODOTYPUS}

Kerria-like (R. kerrioides). A rare shrub from Japan, developing late in summer; numerous pure white flowers.

\section{SPIREA}

Anthony Waterer (S. Watereri). A new hardy variety from England, introduced in this country in 1894. It is of dwarf, dense habit, bearing a profusion of rose-pink flowers of a shade peculiar to itself, blooming the entire summer. The have no doubt this will prove a decided acquisition, and be found desirable either for bedding or pot-plants.

Billards (S. Billardi). Medium-sized shrub, producing spiked panicles of bright rose-colored flowers.

Double-flowered Plum-leaved Spirea (S. prunifolia flore pleno). A beautiful shrub from Japan, with pure white flowers like white daisies, in 


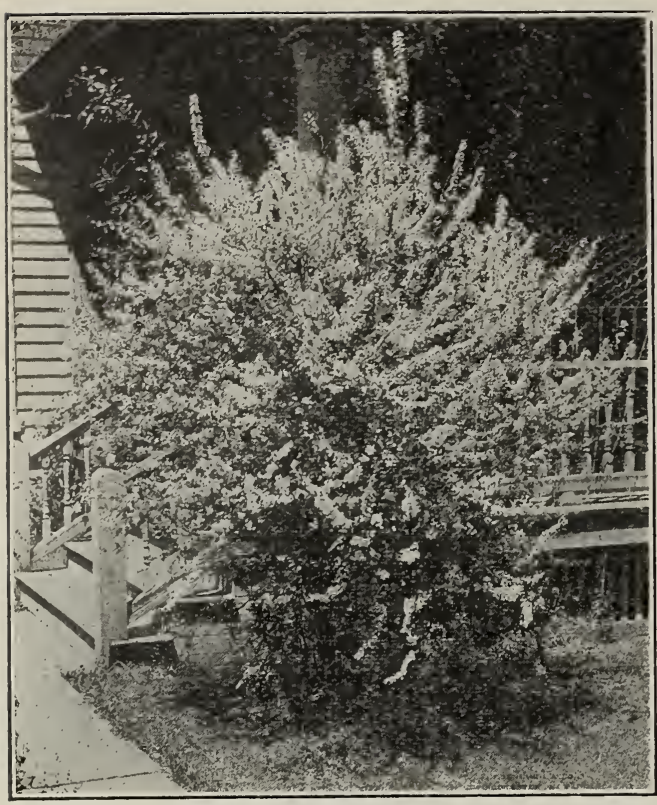

Plum-Leaved Spirea

May. Keeps in flower a long time and justly merits to be placed in the front rank among flowering shrubs.

Douglas' (S. Douglasi). Has spikes of beautiful deep rose-colored flowers in July and August.

Fortune's (S. callosa; S. Fortunei). A choice species; flowers in flattis'! umbels, bright pink, and very showy.

Fortune's Dwarf White (S. callos. alba). A small form of the above, with pure white flowers. Very distinet.

Golden-leaved (S. aurea). A handsome shrub, with bright golden yellow foliage; small white flowers. Very conspicuous and contrasting finely with the deep green of other varieties.

Lance-leaved (S. Reevesiana, or lanceolata). A charming shrub, with narrow pointed leaves and large, round clusters of white flowers, that cover the whole plant and render it exceer. ingly effective. Blooms in June.

S. Fontenaysii. Vigorous and a very free bloomer. Large panicles of greenish white flowers latter part of June.

S. Bumalda. Tn the way of S. callosa, and perhaps a variety of it. Foliage lanceolate; flowers in elusters, rosv pink. Habit dwarf and compact.

S. rosea superba. A very desirable form, with bright rose-colored flowers, blooming freely most of the season.

Thunberg's (S. Thunbergi). A Japanese species of small size, with narrow linear leaves and small white flowers. Unsurpassed for forcing in pots.

Van Houtte's (S. Van Houttei). One of the most attractive of the newer Spireas, blooming freely and entirely harily. l'lowers pure white.

\section{SAMBUCUS. Elder}

Cut-leaved Golden Elder (plumosa foliis aureis). A charming novelty, with beautiful, fern-like, golden foliage, which retains its showy color through the season.

\section{SNOWBALL. Viburnum}

Guelder Rose. (V. sterilis). A wellknown favorite shrub, of large size, with globular clusters of pure white sterile flowers the latter part of Mar.

Plicate (V. plicatum). From north China. Of moderate growth; hantsome, plicatcd leaves; globular heads

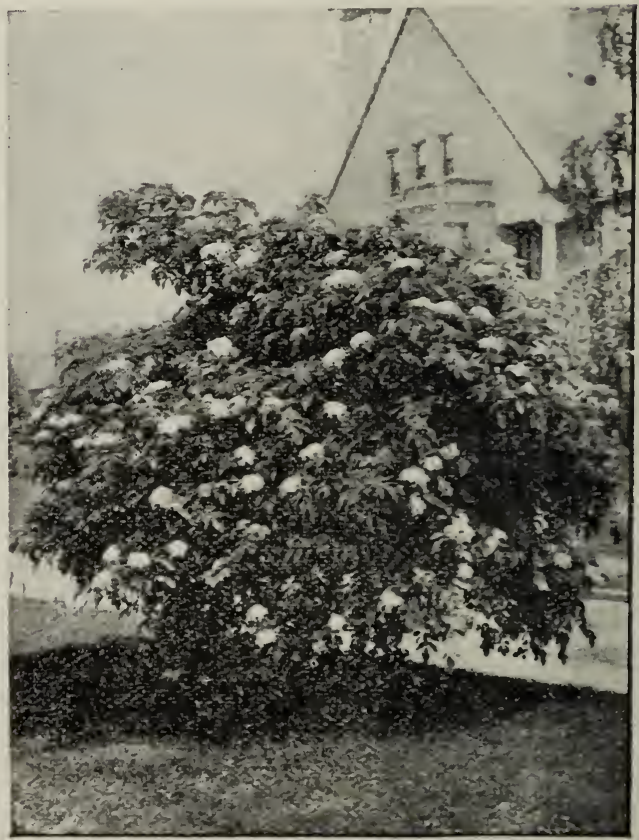

Golden Elder 
of pure white neutral flowers early in June. One of the most valuable flowering shrubs.

Japan (V. tomentosum). The single form of the beautiful Japan Snowball, V. plicatum. Flowers pure white, borne along the branches in flat cymes, in the greatest profusion, early in June. Perfectly hardy, vigorous and free-blooming. Very desirable.

\section{SYMPHORICARPUS.}

\section{St. Peter's Wort, or Wax-Berry. Symphorine, Fr.}

Snowberry (S. racemosus). A wellknown shrub, with small pink flowers, and large white berries that hang on the plant through part of the winter.

Red-fruited, or Indian Currant. (S. vulgaris). A shrub of very pretty habit. Foliage, flowers and fruit small; fruit purple; hangs all winter.

\section{TAMARIX}

These are very beautiful shrubs, with small leaves, somewhat like those of the juniper, and delicate small flowers in spikes, followed by small capsular fruit. Three varieties of flowers in May.

\section{WEIGELA. Diervilla}

Rose-colored (W. rosea). An elegant shrub, with fine rose-colored flowers. Hardy. Blossoms in May.

W. amabilis, or splendens. Of more robust habit; large foliage and flowers,

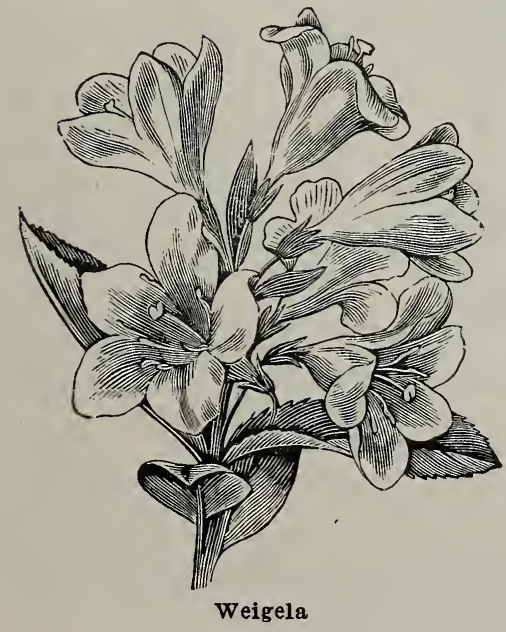

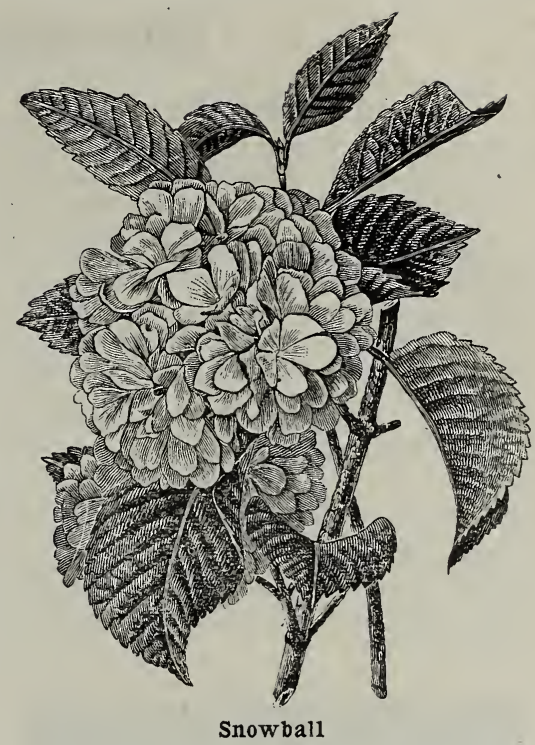

and blooms freely in autumn. A good acquisition.

White-flowered Weigela (W. candida). Of vigorous habit; an erect grower, becoming in time a large-sized shrub, flowers pure white and produced in great profusion in June, and the plants continue to bloom through the summer, even until autumn. A valuable variety.

W. Sieboldii alba marginata. Of upright habit. When the leaves are young the variegation is yellow; when they mature it becomes silvery white; flowers rose-colored.

Variegated-leaved Dwarf Weigela (W. nana foliis variegatis). Of dwarf habit; silvery variegated leaves; flowers nearly white. It stands the sun well and is one of the best dwarf variegated-leaved shrubs. Very desirable.

W. floribunda. A good grower; flowers rather small, crimson, with projecting white stamens. A rich acquisition. Blooms freely in May and occasionally through the season.

W. Lavallei. A fine variety, producing dark reddish purple flowers. One of the darkest varieties. Habit straggling.

W. hybrida Eva Rathke. A charming new Weigela; flowers brilliant crimson; a beautiful, distinct, clear shade. Erect, and very free-flowering. 


\section{Climbing Plants}

\section{AMPELOPSIS}

Japanese Ivy; Japan Creeper (A. Veitchi). Leaves smaller than those of the American, and overlap one another, forming a dense sheet of green. It grows rapidly and clings to wall or fence with the tenacity of ivy; the foliage is very handsome in summer and changes to crimson-scarlet in autumn. For covering walls, stumps of trees, rockeries, etc., no plant is so useful. Probably the favorite of all hardy rines in eities.

\section{AKEBIA}

A. quinata. From Japan. Flowers fragrant, purplish chocolate, opening in June; leaves almost evergreen; fruit ornamental.

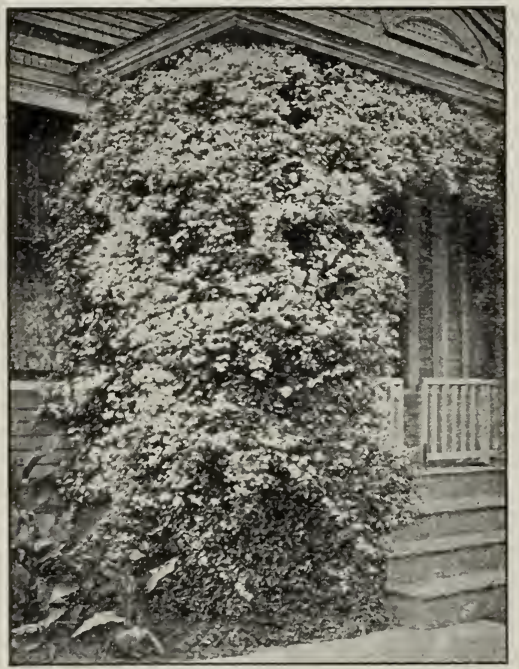

Clematis

\section{CLEMATIS}

Anderson-Henry (C. Henryi). Very large, fine form; free grower and bloomer; ereamy white.

Madame Edouard Andre. Flowers large and of a beautiful bright velvety red; very free-flowering and continnous bloomer.

C. paniculata. A great novelty from Japan. It has proved to be one of the most desirable, useful and beautiful of hardy garden vines, being a luxuriant grower, profuse bloomer and possessing fine foliage. It is par ticularly useful for covering verandas, pillars and fences, where a trellis or support can be provided for it to climb on. The flowers are of medium size, very pretty and fragrant and produced in the greatest profusion in late summer. We can recomment this novelty in the strongest manner as one of the best vines to grow near the house; it makes a growth of from 25 to 30 feet in a single season ancl should be cut back to the grount each spring.

Duchess of Edinburgh. A very fine shade of white, with double flowers. Very attractive.

C. Jackmani superba. Immense flowers, 4 to 5 inches in diameter; exquisite deep violet-purple color; very rich and handsome. Bears great masses and wreaths of flowers; comes into bloom quickly, and continues a long time. Exceedingly beautiful variet:.

\section{HONEYSUCKLE. Lonicera}

Chinese Twining (L. Japonica). A wellknown vine, holding its foliage nearly all winter. Blooms in July and September and is very sweet.

Japan Golden-leaved (L. aureo reticulata). The most beautiful variety of this class of climbers; leaves of bright green and golden yellow; exquisitely beautiful. Fine for bodding, pot culture or for lianging baskets. Perfectly harty; will give entire satisfaction.

Monthly Fragrant (L. Belgica). Sweetscenter. Fine; continues to bloom all summer.

\section{JESSAMINE}

Naked-flowering (J. mutiflorum): Produces golden yellow flowers very early in the spring, before the foliage appears.

\section{TRUMPET VINE. Bignonia}

Chinese (B. grandiflora). Self-climber. This beantiful species bears large rellowish scarlet flowers.

Common Trumpet Vine (B. radieans). Self-climber. A most useful, stronggrowing native vine, elinging tightly to whatever its growing shoots touch and bearing clusters of scarlet flowers in July and Angust. 


\section{WISTARIA. Glycine}

W. Sinensis (Chinese). One of the most splendid and rapid-growing plants; has long pendent clusters of pale blue flowers in spring and autumn.

W. Sinensis alba. Similar to $W$. Sinensis, except that the flowers are white; forms a fine contrast to that variety.

\section{Herbaceous Peonies}

It is surprising that so noble a flower, almost rivaling the rose in brilliancy of color and perfection of bloom, and the rhododendron in stately growth, shrould be so neglected. Amateurs seem to have lost sight of the many improved varieties introduced within the last few years, and our finest gardens, perfect in other respects, are singularly deficient in specimens of the newer kinds. The first point in their favor is hardiness. It may be truly said of them that they are "hardy as an oak." In the severest climate the plants require no other protection than that which they afford themselves. Then their vig. orous habit and healthy growth, freedom from all diseases and insects are important arguments in favor of their cultivation. Growers of roses know well that their flowers are obtained by great vig. ilance and care. Not so with the Peony, with which when once planted all is done. Each succeeding year adds to their size and beauty. The foliage is rich and glossy and of a beautiful deep green color, thus rendering the plants very ornamental even when out of flower. The newer varieties produce very large, handsome, regularly formed cupped blooms resembling large roses. No other flower is so well adapted for large, showy bouquets. The Peony may be planted either singly on the lawn or in borders. Where the lawn is extensive a large bed

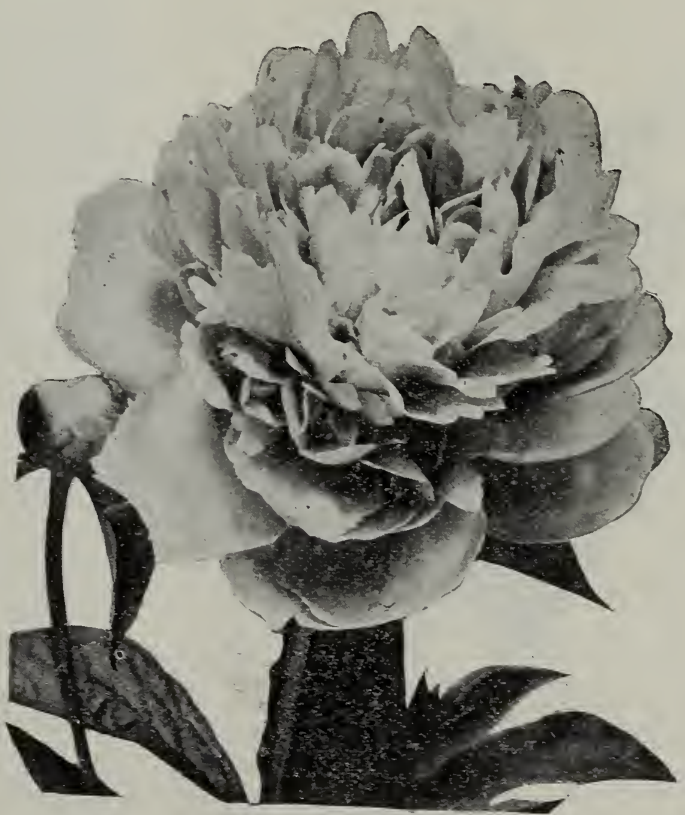

Herbaceous Peonies makes a grand show, surpassing a bed of rhododendrons.

The Peony plants I supply are all of the best varieties grown, and will be sure to give complete satisfaction in every respect 


\section{Everblooming Roses}

The Everblooming Tea Roses are universally regarded as the most desirable and valuable Roses for general planting in the open ground; they commence to flower almost as soon as they are planted, and continue throughout the entire season; flowers, increasing in size and beauty until late in autumn, are noted for their exquisite delicacy of coloring and their delightful fragrance. They will stand severe winters in open ground with good protection. For quick and satisfactory results, plant the everblooming Roses from $2 \frac{1}{2}$ inch pots, which will give more satisfaction. The following is a selection from the handsomest and best bloomers.

American Beauty. An excellent Rose for forcing. The flowers are very double, of a deep crimson color and very fragrant.

Bride. This is decidedly the most beautiful white Tea Rose. It is a sport from Catherine Mermet, with which it is identical in growth and shape of flowers. The flowers are very large and double, on long, stiff stems, of fine texture and substance, and last a long time in a fresh state after being cut, making it one of the best varieties for corsage wear or bouquets.

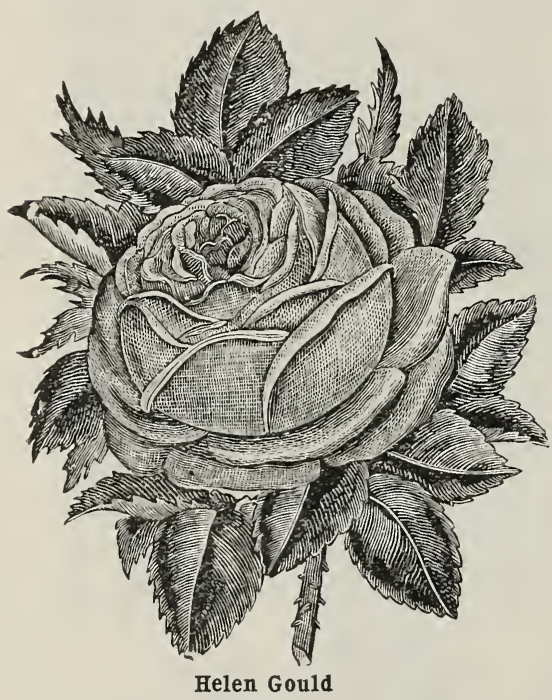

Bridesmaid. This is a superb pink Rose for outdoors and for forcing. More of it is used than all other pinks combined. We rank it next to Maman Cochet. In some places it is ranked first, having a more refined flower than Maman, the latter growing so immense in size as to be deemed coarse when compared with Bridesmaid. It is hard to beat.

Catherine Mermet. A beautiful, clear flesh-color, with the same silvery luster seen in La France. Large, full, well formed, very beautiful in bud. Still one of the finest and best forcing Roses.

Clothilde Soupert. Its color is a pearl white, with a vivid carmine-rose center, which fades after a little, leaving the Rose almost white. It is a constant bloomer, quite fragrant, and cannot fail to be a splendid market plant for growing in pots for spring sales. In addition to its suitability for market purposes, it will be very useful to the cutflower worker, forming as it does, nice sprays of open flowers and half-open buds.

Double Papa Gontier (Christine de Noue). The buds are long and finely pointed, the color a clear, rich maroon or deep purplish red, passing to lake, center sometimes streaked silvery white. Petals finely imbricated and the flowers deliciously sweet. More valuable than Papa Gontier, as fine a color, forces as well, has a larger bud, and is perfectly double.

Etoile de Lyon. This is considered one of the finest yellow bedding Roses for outside planting. It is, moreover, one of the hardiest in the Tea section. It blooms freely, and every flower is a gem. It equals Marechal Niel in size, on strong bushes.

Golden Gate. It is a strong, healthy grower, excellent for both bedding and house culture. Produces a profusion of long, pointed buds, opening to very large double Roses of creamy white, beautifully tinted with soft yellow at the base of the broad petals, which are exquisitely bordered with clear rose. We heartily recommend it.

Helen Gould (Balduin). This Rose was first sent out under the name of Balduin, but has been rechristened the more appropriate name of Helen Gould. This is probably the most beautiful and satisfactory Rose for general planting ever introduced in America. It has proved itself to be the strongest-growing, freest-blooming, largest flowering and hardiest Rose in existence. It is a better Rose for general planting than American Beauty - the dream and hope 
of every rose-grower for years past. The flowers are full and perfectly double, the buds beautifully made, long and pointed. The color is a warm, rosy crimson, like the color of a ripe red watermelon. It is as hardy as La France.

Hermosa. An old favorite. It is always in bloom and always beautiful. The flowers are cupped, finely formed and full. Color the most pleasing shade of pink, soft, but deep. The best market Rose grown.

Kaiserin Augusta Victoria. This beautiful Rose has not only a royal name, but is a royal Rose as well. We have white Roses that have elegant buds, but when full blown are not all that is desired. Then again, we have white Roses that are elegant when full blown, but have poor buds. This Rose combines both these good qualities. It is a continuous bloomer, producing successive crops of buds, and formed with large petals of best substance; shows no center when fully open. Color a pure snowy white.

Ia France. No variety can surpass it in delicate coloring-silvery rose shades, with pink. It has a satin sheen over all its petals. It is universally regarded as the most useful of Roses, for it is hardy beyond question. It blooms continuously.

Mademoiselle Franciska Kruger. This is a rose for the millions to plant. It is a vigorous grower, very free bloomer, and, while the color is variable at different seasons of the year, it is always beautiful. In warm weather it takes on lovely red shades, while in cooler weather it turns to a deep, coppery-yellow, always pretty in every stage of development. A Rose everybody can succeed with.

Madame de Watteville. This grand new everblooming Rose is one of the most beautiful varieties we have ever sent out, and is very largely planted by those who know its beauty. The color is a remarkable shade of creamy yellow, richly covered with rosy blush. The petals are large and each one widely bordered with bright crimson, which gives it a very striking and beautiful appearance.

Madame Eli Lambert. A beautiful new Tea Rose. Color is somewhat in the way of Madame de Watteville, but deeper, rich, creamy white, faintly tinted with pale golden yellow, and exquisitely bordered and shaded with soft rosy flesh, exceedingly beautiful and very sweet.
Madame Welche. An extra-fine variety, very large, double and of beautiful rounded form; a soft, pale yellow, sometimes cream, with short, inner petals of glowing orange and copper. Not to be forgotten if once seen.

Maman Cochet. One of the best new Roses. The growth is vigorous, with rich, healthy foliage. The extra large flowers produced on long stems, are very rouble, and the buds and half-expanded flowers are simply exquisite in their graceful form, delicate color and rich fragrance. The color is deep rosepink.

Meteor. A velvety red ever-bloomer, of the deepest glowing crimson. As fine as a hybrid; flower of medium size, very double, and petals slightly recurving. A beautiful open Rose, a free bloomer and promising well as a pot Rose. It has no tinge of violet or purple to mar its beauty. It promises to be a reliable ever-bloomer, free from bad qualities. The best rich red Rose that was ever introduced for florists' use.

New Crimson Rose, (Virginia $\mathbf{R}$ Coxe) or Crimson Hermosa (Gruss an Teplitz). This grand Rose has proved one of the best and most valuable Hardy Crimson Ever-blooming Roses for garden planting ever introduced. The color when first opening is dark rich crimson quickly passing to velvety fiery red, one of the very brightest colored Roses we know. Flowers large, full and sweet; very showy and handsome; blooms constantly, throwing up fresh buds and flowers the whole growing season. The bush is a healthy, vigorous grower, entirely hardy here with usual winter protection.

Safrano. One of the best of all the coppery-colored varieties; foliage large, growth very vigorous, and flower large, yellow margin shading to a deep coppery. Too good a Rose for this price.

Souv. de Pierre Notting (Tea). This variety is a seedling of $M$. Niel and Maman Cochet, with beautiful closely set foliage and a strong, sturdy habit of growth. The bloom is very large, perfectly full, of elegant form-has a beautiful long bud, the colors are very bright, distinct and clear, and have no unpleasant tones-orange-yellow, bordered in carmine-rose. Promises to prove very popular. Has received not less than six gold medals and prizes.

Souvenir du President Carnot. With all our admiration for the hosts of beautiful Roses, this variety is so fascinating that we believe it to be, everything considered, one of the greatest introductions of the last ten years. It 
is superb in every way. The flowers are large, full and double, exquisitely shaped, with heavy, thick, shell-like vetals. The buds are wonderfully beautiful-long and pointed like Niphetosperfection in every line. The color is a new, delicate rosy blush, shaded a trifle deeper at center of flower. Fragrance delicious; strong grower anil tree bloomer; has no weak point; will become one of the most popular of all Roses.

Souv. de la Malmaison. This grand old variety, when used as a bedding Rose in summer, has no equal, as it produces the most perfect flowers in the hottest weather. Its rich, flesh-colored flowers are of immense size, are produced in abundance, and have the requisite form and substance to withstanil our hot, dry summers.

The Burbank Rose. A perfectly hardy, new, Everblooming Rose. This lovely Rose was raised by $\mathrm{Mr}$. Luther Burbank, of California, known the world over as the "Wizard of Horticulture," and is the only variety out of seventy-five thousand cross-bred seedlings which he raised that he was willing should bear his name. The Rose is the only rival that the famous variety Champion of the IVorld has. The color is described as cherry-crimson-it is, in other words, the very deepest and brightest pink Rose in cultivation. It is peculiarly adapted for both outdoor planting and for blooming in pots in the house during the winter. It is a strong, vigorous grower, making wellrounded, bushy plants. The Burbank Rose is perfectly hardy and will stand our most severe weather. This is a decided point in its favor over so many of our lovely Roses, they being too tender to withstand the extreme cold. The Burbank can be planted anywhere. The Burbank is, without doubt, the freestflowering Rose in cultivation. It commences to bloom when only a few inches high, and blooms throughout the season until stopped by freezing weather. The flowers are double, three inches across. The whole flower is most pleasing in its rich beauty, and is delightfully fragrant.

Yellow Cochet, or Madame Derepas Matrat. A pure Tea Rose, very free-growing and hardy in its character. It throws up fine, strong stems, crowned by solitary buds of grand size; the color is a good sulphur-yellow on first opening, changing to a delightful rose color as the flower gets age, when it takes on the Rose shade. It cannot be distinguished from White Maman
Cochet. Will probably rank with the Cochets. Blooms very large, perfectly double, splendid form and freely produced. It has every quality necessary to make the ideal yellow bedder, ranking with the White and Pink Cochets in value as a Summer Rose.

White La France (Augustine Guinnoiseau). Here we have a beauty indeed, one we recommend to all, whether for outdoor culture or for pots in the house in winter. If you were to ask us to select six of the very finest Roses for you, we should be sure to include it in the six. Do you know La France? If so, you know this elegant new Rose. It is identical with La France, except the color-pearly white, sometimes tinted with fawn.

White Maman Cochet, or Priscilla. The charming new White Tea Rose. Another new American Rose. It belongs to the Tea class, being a child of that grandest of bedding or outdoor Roses, Maman Cochet, and is hardy in the northern states, with slight protection in winter. Its habit is exceedingly strong and upright, like its parent, and it possesses the same large, beautiful, healthy foliage, and is a profuse and constant bloomer. The flowers are of enormous size, remarkably round and full, pure, clear, snowy white throughout, and are delightfully Tea-scented. It is by far the finest and most reliable white bedding Rose yet produced. Any one can have the finest Roses for cutting all summer and autumn by planting a few plants of it. It is without doubt the largest white Rose, both in bud and flower.

\section{HYBRID PERPETUAL ROSES}

Anna de Deisbach (Glory of Paris). Brilliant crimson-maroon; extra large, very full and sweet; an excellent bloomer.

Baroness Rothschild, mod. or dwf. (Pernet, 1867.) Light pink; cuppeil form; very symmetrical; without fragrance. Very distinct and beautiful; one of the finest exhibition varieties. The wood is slort jointed; very hardy and a late bloomer. Budded plants.

General Jacqueminot. Bright red, fragrant. Extra. This is too wellknown to need description.

John Hopper. An excellent rose: hardy and abundant bloomer, solid and regular flowers, perfectly double, clear, bright, rosy pink, very fragrant.

Margaret Dickson. New, pure white, with rosy flesh center, large shellshaped petals, beautiful. 
Marie Baumann. Deep bright red, large flowers, broad thick petals, exquisite form, one of the best.

Marshall P. Wilder. Extra large, full flowers, dark, deep red, free bloomer: very handsome.

Mrs. J. H. Laing. A grand, free blooming Hybrid Perpetual, with fine flowers of soft, delicate pink, with satin cast.

Paul Neyron. A magnificent Rose, one of the largest and finest of all; clear, shining pink; very double, full and fragrant.

Pierre Notting. Grand size, round and full; deep, dark red, one of the best.

Prince Camille de Rohan. Very dark, relvety crimson, almost black; darkest of all.

Ulrich Brunner. Splendid upright grower, with bright, healthy foliage. The flowers are good-sized and of fine form, with shell-shaped petals. One of the most abundant bloomers; color. eherry red.

\section{CLIMBING ROSES}

Mrs. Robert Peary (Climbing Kaiserin). This is without doubt the grandest of all white climbing Roses. It is the first and only pure white hardy, everblooming climbing Rose, and as such meets a demand that has never before been supplied. Small plants bloom continually the first season, just as the parent Kaiserin Augusta Victoria does. It is as hardy as any Hybrid Perpetual or Moss Rose, and will withstand, unprotected, the most severe winters. It is a strong, rapid grower, without a weak spot, growing to perfection in open ground, anil throwing up numerous shoots 10 to 15 feet high in a single season. The flowers are something grand. They are the equal of the finest and most beautiful cut-flower Roses. Of splendid substance. They are extra large, full, deep and double, and are produced on long, stiff stems, like a forcing or cutflower Rose. The buds are long and pointed, exquisitely modeled and gracefully finished. Both in bud and flower it is truly beautiful. It has a fragrance that is delicious, just like cherry blossoms. If you want a quickgrowing, absolutely hardy, climbing, sure to bloom Rose, one that will give you flowers this season, this is the only white variety that will do. Be sure to get this wonderful variety. Its magnificent flowers, freedom of bloom and healthy growth will astonish you. This is the greatest of all climbing Roses.

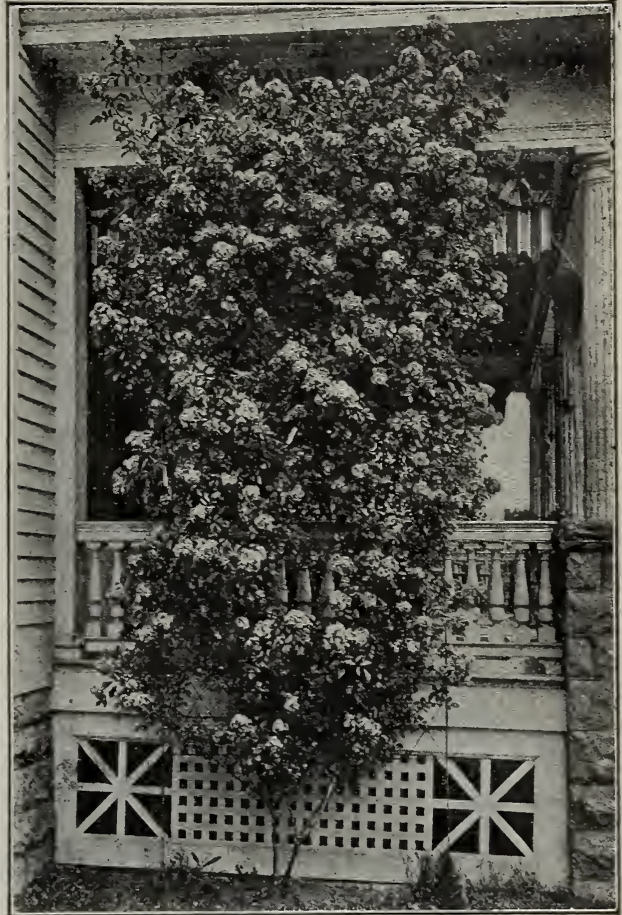

\section{Crimson Rambler}

Climbing Meteor. Grand New Velvety Red Rose. The brightest colored of all Roses. It has been called a Perpetual Blooming Climbing General Jacqueminot. All who know "Gen. Jack", will eall to mind its beautiful, high-colored, rich; velvety red buds and flowers. Climbing Meteor is the acme of all red climbing Roses. It is a free, persistent bloomer, and will make a growth of from ten to fifteen feet in a season. In bloom all the time, as it is a true ever-bloomer. We do not hesitate to place it at the head of the list of all Roses for summer blooming, as it will make a strong growth and is literally loaded with its deep, rich red flowers all the time. Its flowers are much larger than Meteor, and are rich in color. It is just the Rose to train up to the veranda or around windows, where its great beauty will show up to advantage. Don't fail to plant one or more Climbing Meteors.

Crimson Rambler. Imported from Japan, the land of wonders. It is a rapid grower and very quickly makes heavy canes of great length, covered with peculiar, shining foliage. Blooms are produced in great bouquets, and are 
of a most peculiar and lovely shade of crimson. It has proved perfectly hardy, even in the niost rigorous climate. A bed of this pegged down and requiring little attention would be very useful to the general florist at blooming time. It also makes a fine potplant, treated and brought on like the early blooming Hybrid Perpetuals, and forms a perfect bouquet of bloom. This is without question the handsomest plant of any description for Easter blooming. Grow in the field one or two years (the latter age is the best), dig and pot and keep cool at night for about six weeks, until root action is active, then gradually increase temperature. Treated this way this Rose produces, from the very pot to its topmost branches, huge bunches of from fifty to two hundred blooms in a cluster, and is a sight not soon to be forgotten.

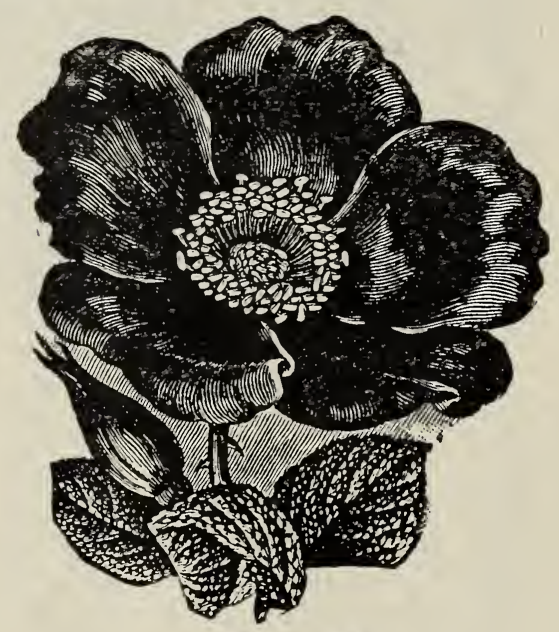

Japan Rose

Reine Marie Henriette. A strong, vigorous grower; flowers large, full and of fine form. Color a pure cherry-red, and sweet-scented.

Yellow Rambler (Aglaia). Rosarians have been for many years crossing or hybridizing various Roses with a view to obtaining a hardy yellow climbing Rose, but the combination of climbing habit and yellow coloring with hardiness was one that seemed impossible to obtain, and was almost despaired of. The Yellow Rambler has been found to successfully withstand, without protection, a continued temperature of from zero to two below, which proves it to be far hardier than any other yellow climbing Rose yet introduced, and we believe that by laying the plants down in the winter it can be successfully grown in nearly all the northern parts of the United States; in fact, anywhere that other Roses succeed at all well. Dirl we say nothing more about the Rose we think this would be sufficient to establish its value, for what lover of Roses in the North has not bewailed the severity of the climate which nearly deprives his garden of the most at. tractive color of all-yellow. The Howers are borne in immense clusters, after the same manner as the Crimson Rambler, often as many as one hundred and fifty blooms in a bunch. The color is a decicled yellow.

\section{ROSA RUGOSA}

Rosa Rugosa Alba. White flowers, golden fruit; a strong, vigorous grower, with magnificent foliage. Very free and branching, and every tip laden with immense bouquets of large white Roses.: Perfume exquisite.

Rosa Rugosa Rubra. Crimson flowers and fruit. Same habit as above, except the flowers and fruit are red.

\section{HYBRID WICHURIANA ROSES.}

Creeping Rose (Rosa Wichuriana). vig. Pure white, single, extra good.

Evergreen Gem. A very vigorous grower. The flowers are single and light yellow. Fine.

Gardenia. Bear's beautiful double, light, yellow flowers, resembling a Cape Jasmine bloom in shape. Beautiful.

Jersey Beauty. Vigorous flowers. Single, pale-yellow, with stamens golden-yellow.

Manda's Triumph. Produces large clusters of well-formed, double flowers of pure white, two inches in diameter.

Multiflora. A very vigorous sort, making a heavy bush with beautiful pendulous branches which are hidden -in the masses of creamy white flowers. of the very first nuerit, and worthy of general use as a climber or shrub.

Pink Roamer, vig. Pink.

Prairie Rose (Rosa Setigera) vig. Light pink, single, very desirabls.

Rosa Carolina. This is the tall growing wild Rose, so pretty in late June when full of its single pink flowers. It bears fruit freely, and the bright red color of this is most attractive in the late fall. It thrives in damp soil as well as in high ground, and is particularly useful for massing.

South Orange Perfection, vig. Soft blush pink, changing lighter, double, fine.

Sweet Briar (Rosa Rubiginosa) vig. Bright pink, single, very desirable. 


\section{N D EX.}

\begin{tabular}{|c|c|}
\hline $\begin{array}{r}\text { Page } \\
\ldots 26\end{array}$ & amme. \\
\hline 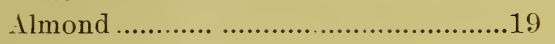 & \\
\hline lthea ......... & \\
\hline morpha........... & \\
\hline mpelopsis............ & 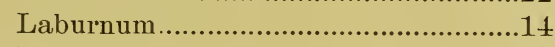 \\
\hline pples ..................... & \\
\hline & \\
\hline rborvitæ .............. & \\
\hline 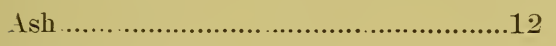 & mbar ... \\
\hline 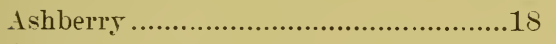 & \\
\hline us .............. & \\
\hline$\ldots 19$ & \\
\hline arberry ............... & - 2 - \\
\hline eech...................... & \\
\hline $\operatorname{reh} \ldots \ldots \ldots \ldots \ldots \ldots$ & \\
\hline erries ............. & $\ldots .2$ \\
\hline$\ldots 18$ & \\
\hline$\ldots 20$ & \\
\hline $\mathrm{s} \ldots \ldots \ldots \ldots$ & \\
\hline ..........12.13 & \\
\hline$\ldots \ldots .4$ & \\
\hline $\mathrm{s}$ & 6,23 \\
\hline (n) & $.15,16$ \\
\hline Plants..... & $\ldots 23$ \\
\hline ......20 20 & \\
\hline$\ldots 17,18$ & $\ldots 23$ \\
\hline .....1:3 & \\
\hline …................. 8 & ..... 9 \\
\hline . & \\
\hline s Shrubs... & .......17 \\
\hline ........12-16 & $\ldots 18,19$ \\
\hline 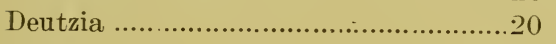 & .........23 \\
\hline …..................13.20 & .......11 \\
\hline 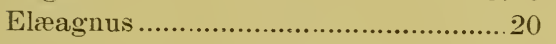 & $.28-32$ \\
\hline ............13 & $\ldots \ldots .24$ \\
\hline 8.21 & .........24 \\
\hline os ........................18.19 & $\ldots \ldots \ldots \ldots \ldots \ldots \ldots \ldots \ldots \ldots \ldots \ldots \ldots \ldots \ldots \ldots \ldots \ldots \ldots \ldots \ldots \ldots \ldots, 23,24$ \\
\hline …............................ & $\ldots \ldots .17$ \\
\hline 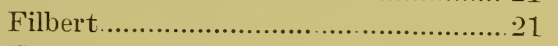 & .............. \\
\hline 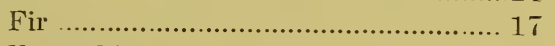 & $\ldots \ldots .16$ \\
\hline 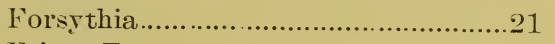 & ................. 16 \\
\hline 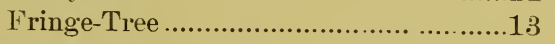 & $\ldots \ldots \ldots \ldots \ldots \ldots$ \\
\hline $.1 \pm$ & ........25 \\
\hline ......... 8 & $\ldots 16.19$ \\
\hline …......... & ..............26 \\
\hline$\ldots \ldots \ldots \ldots \ldots .18$ & .........16 \\
\hline$\ldots \ldots .21 .26$ & $\ldots 25$ \\
\hline$\ldots \ldots . .13$ & $\ldots 16$ \\
\hline 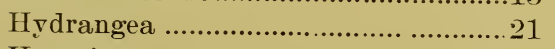 & (........................... \\
\hline $\mathrm{n}$ & 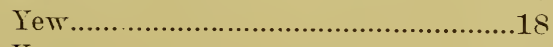 \\
\hline 1 & Y \\
\hline & \\
\hline
\end{tabular}




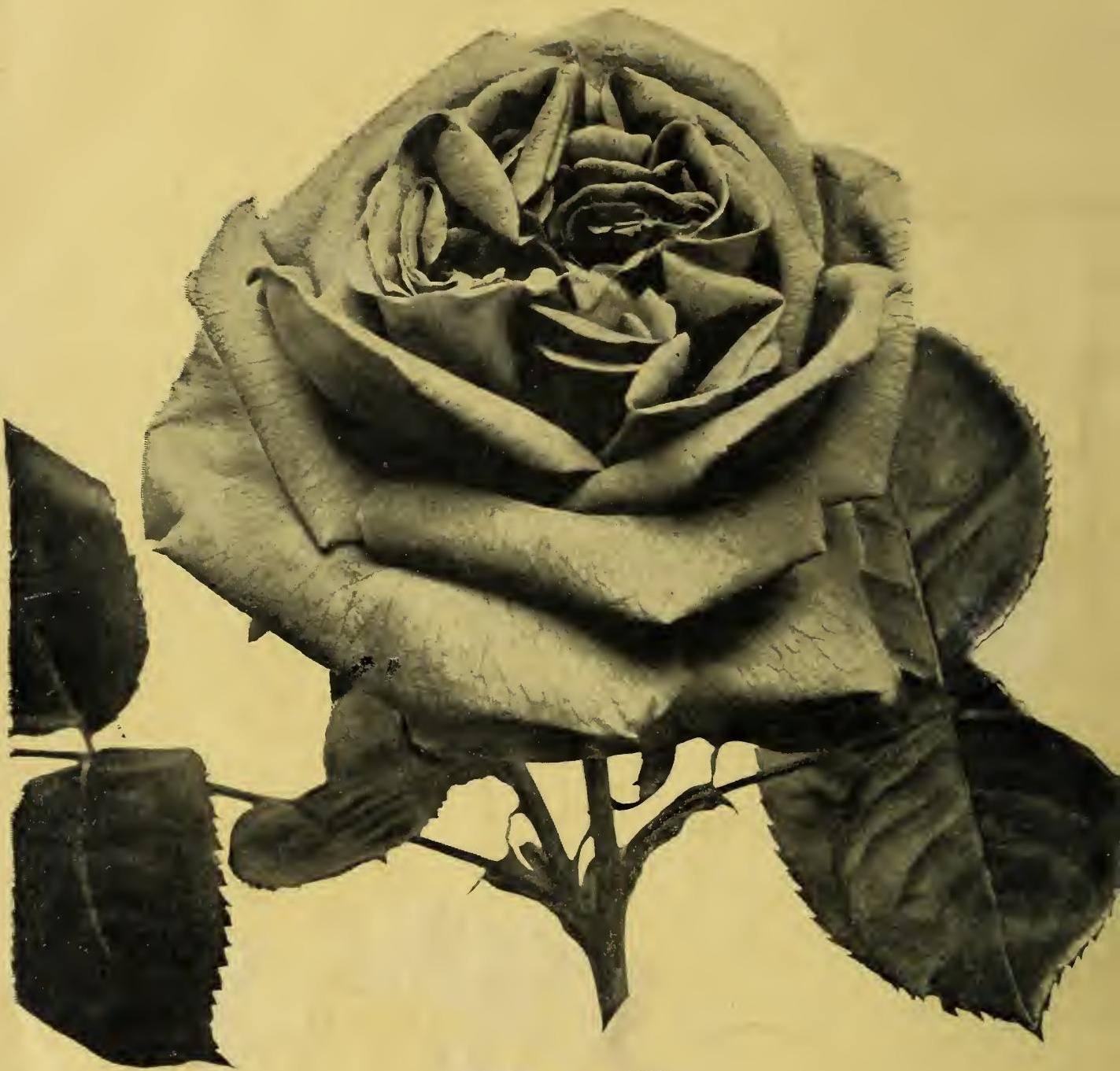

Marshall P. Wilder

VREDENBURG \& CO.. PRINTERS. INC., ROCHESTER N. Y. 